1

2

3

4

5

6

7

8

9

10

11

12 *These authors contributed equally to this work.

13

14

15

16

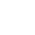
chenzhu@indiana.edu.

\title{
SUPCRTBL: A revised and extended thermodynamic dataset and software package of SUPCRT92
}

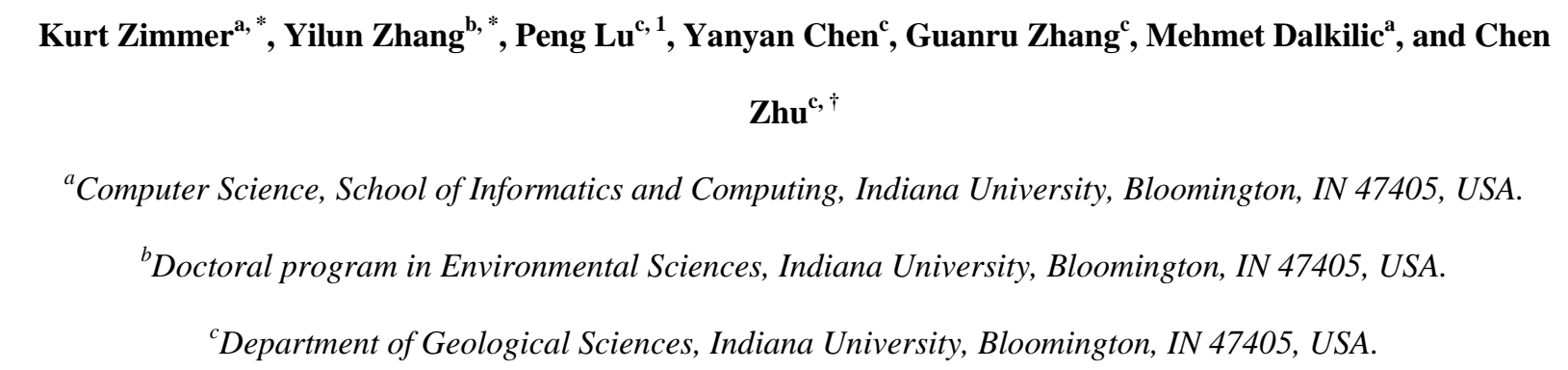

${ }^{\dagger}$ Corresponding author, Tel.: +01-812-856-1884; fax: +01-812-856-2223. E-mail address:

${ }^{1}$ Now at EXPEC Advanced Research Center, Saudi Aramco, Dhahran, 31311, Saudi Arabia. 
Abstract

The computer-enabled thermodynamic database associated with SUPCRT92 (Johnson et

20 al., 1992) enables the calculation of the standard molal thermodynamic properties of minerals,

21 gases, aqueous species, and reactions for a wide range of temperatures and pressures. However,

22 new data on the thermodynamic properties of both aqueous species and minerals have become

23 available since the database's initial release in 1992 and its subsequent updates. In light of these

24 developments, we have expanded SUPCRT92's thermodynamic dataset and have modified the

25 accompanying computer code for thermodynamic calculations by using newly available

26 properties. The modifications in our new version include: (1) updating the standard state

27 thermodynamic properties for mineral end-members with properties from Holland and Powell

28 (2011) to improve the study of metamorphic petrology and economic geology; (2) adding As-

29 acid, As-metal aqueous species, and As-bearing minerals to improve the study of environmental

30 geology; (3) updating properties for Al-bearing species, $\mathrm{SiO}_{2}{ }^{\circ}(\mathrm{aq})$ and $\mathrm{HSiO}_{3}{ }^{-}$, boehmite,

31 gibbsite, and dawsonite for modeling geological carbon sequestration. The new thermodynamic

32 dataset and the modified SUPCRT92 program were implemented in a software package called

33 SUPCRTBL, which is available online at http://www.indiana.edu/ hydrogeo/.

34 Keywords:

35 SUPCRT92; arsenic; geological carbon sequestration; thermodynamic properties; geochemical 36 modeling; chemical equilibrium 
1. Introduction

Oelkers et al. (2009) state that the creation of thermodynamic databases may be one of

40

41

42

43

44

45

46

47 the past century's greatest advances in the field of geochemistry. These databases make it possible for quantitative interpretation and predication of geochemical systems. For example, the computer-enabled thermodynamic database affiliated with the computer program SUPCRT92 (Johnson et al., 1992) has greatly increased the efficiency of thermodynamic calculations.

Furthermore, equilibrium constants generated from SUPCRT92 are basic input parameters for a variety of geochemical and reactive transport modeling codes (e.g., Toughreact, Phreeqc, Phast, The Geochemist's Workbench, CHESS, CrunchFlow and HydroGeochem). These "higher order" codes have facilitated rapid chemical speciation, reaction path, and reactive mass transport simulations. The near 2000 citations of Johnson et al. (1992) are testimonial to the great contribution of this work to the geological community.

The thermodynamic database embedded in SUPCRT92 is based on the compilation of a variety of thermodynamic datasets, extrapolations, estimates reported by Helgeson and coworkers (Dale et al., 1997; Haas et al., 1995; Helgeson et al., 1978; Sassani and Shock, 1998; Schulte and Shock, 1993; Shock, 1992, 1993; Shock, 1995; Shock and Koretsky, 1993; Shock and Koretsky, 1995; Shock and McKinnon, 1993; Shock et al., 1997a ; Sverjensky et al., 1997). The original SUPCRT92 database contains a limited number of minerals and aqueous species, whereas the applications of geochemical and reactive transport modeling for a variety of geological and environmental topics require a wide range of minerals and aqueous species. The database of SUPCRT92 has gone through a series of updates since its initial publication because of the need for a wider range of minerals and aqueous species. Some notable updates include 
sprons96.dat, slop98.dat, and slop07.dat (GEOPIG, 2010). Sprons96.dat included aqueous and mineral species relevant to the disposal of high-level nuclear wastes, while slop98.dat and slop07.dat focused on the addition of metal-organic complexes and other organic compounds. The mineral data in these three updates have remained largely unchanged since 1992 (from Helgeson et al. (1978), i.e., HDNB). The HDNB database was one of the earliest and most widely used internally consistent datasets of standard state thermodynamic properties for mineral end-members. The experimental data that it was based on, however, was mostly compiled before 1975; therefore, it is necessary to upgrade and expand the database by incorporating new data available on phase equilibrium constraints, calorimetry, and field data. Additionally, one major difference between the HDNB database and the newly upgraded and expanded database HP11 (Holland and Powell, 2011) is the treatment of the temperature and pressure dependence of mineral volumes. HDNB assumes mineral volumes are independent of temperature and pressure. It has since been recognized, however, that expansibilities and compressibilities can have significant effects on calculated Gibbs free energies of minerals (Berman, 1988; Holland et al., 1996; Pawley et al., 1996).

Currently, there is a tremendous amount of interest in arsenic geochemistry because of arsenic contamination in groundwater (Fukushi and Sverjensky, 2007; Lu and Zhu, 2011; Marini and Accornero, 2007, 2010; McKnight-Whitford et al., 2010; Nordstrom and Archer, 2002;

\section{Oremland and Stolz, 2003; Smedley and Kinniburgh, 2002; Sverjensky and Fukushi, 2006;}

Swartz et al., 2004). Significant discrepancies, nonetheless, still exist in the thermodynamic data for arsenic aqueous species and minerals in the literature. New values of thermodynamic properties for arsenic species have become available through several re-evaluations, compilations, estimations, or experiments (Langmuir et al., 2006; Marini and Accornero, 2007, 
83 2010; Nordstrom and Archer, 2002; Pokrovski et al., 2002; Zhu et al., 2005). We have compiled

84 the available data for the As-O-H-S-Fe-Ba system ( $\mathrm{Lu}$ and Zhu, 2011) and incorporated them

85 into our new thermodynamic database here.

86 In the last decade, a significant amount of research has focused on determining the

87 feasibility of storing large amounts of $\mathrm{CO}_{2}$ in deep geologic formations in order to reduce carbon

88 dioxide emission into the atmosphere. Dissolution of the injected $\mathrm{CO}_{2}$ will acidify the formation

89 water and cause significant water-rock interactions that dissolve aluminosilicate minerals and

90 precipitate carbonates (IPCC, 2005). In order to better simulating these reactions, we have

91 updated the $\mathrm{Al}$ and Si-bearing aqueous and mineral species and some carbonate minerals in the

92 new database.

93

94 2. Updates to the Database

95 2.1. Updates for minerals of petrological interest

The variation of standard Gibbs free energy at any temperature and pressure can be

97 computed by the equation (Anderson, 2008)

98

$$
\Delta_{a} G_{T, P, i}^{o}=\Delta_{f} G_{T_{r}, P_{r}, i}^{o}+\int_{T_{r}}^{T}\left(\frac{\partial G_{i}^{o}}{\partial T}\right)_{P=P_{r}} d T+\int_{P_{r}}^{P}\left(\frac{\partial G_{i}^{o}}{\partial P}\right)_{T} d P
$$

99 where $\Delta_{a} G_{T, P, i}^{o}$ refers to the apparent molar Gibbs free energy of formation from the elements of

100 the subscripted substance $i$ at the temperature $T$ and the pressure $P . \Delta_{f} G_{T_{r}, P_{r}, i}^{o}$ denotes the

101 standard molar Gibbs free energy of formation from the elements of the subscripted substance at

102 the reference temperature $T_{r}$ and pressure $P_{r} . G_{i}^{o}$ stands for the Gibbs free energy of the

103 subscripted substance. 
104 Integrating the second term and considering the relationship $\left(\frac{\partial G}{\partial P}\right)_{T}=V$, Eq. (1)

105 becomes

106

$$
\Delta_{a} G_{T, P, i}^{o}=\Delta_{f} G_{T_{r}, P_{r}, i}^{o}-S_{T_{r}, P_{r}, i}^{o}\left(T-T_{r}\right)+\int_{T_{r}}^{T} C_{P i}^{o} d T-T \int_{T_{r}}^{T} C_{P i}^{o} d \ln T+\int_{P_{r}}^{P} V_{i}^{o} d P
$$

107

108

109

110

111

112

113

114

115

116

117

122 where $S_{T_{r}, P_{r}, i}^{o}$ refers to the standard molar entropy of the subscripted substance at the reference temperature and pressure. $C_{P i}^{o}$ and $V_{i}^{o}$ stand for the standard molar isobaric heat capacity and volume of the substance of interest, respectively.

Helgeson et al. (1978) indicated that mineral expansibilities and compressibilities in the Earth's crust are small because most minerals expand less than 3\% with temperature increasing from 25 to $800^{\circ} \mathrm{C}$ at 1 bar. Most minerals compress by less than $4 \%$ with increasing pressure from 1 bar to 40 kbars. Thus, past researchers have posited that the pressure and temperature effects on volume cancel out each other, and that mineral volumes can be approximated as being independent from temperature and pressure. Considering these assumptions, the last term of Eq. (2) becomes

$$
\int_{P_{r}}^{P} V_{i}^{o} d P=V_{i}(P-1)
$$

Holland and Carpenter (1986); Holland et al. (1996); Pawley et al. (1996), however, have argued that mineral expansibilities and compressibilities can have significant effects on calculated Gibbs free energies at high temperatures and pressures. Holland and Powell (2011) gave the $G$ contribution by integrating $V$ of the last term of Eq. (2):

$$
\int_{P_{r}}^{P} V_{i}^{o} d P=P V_{i}^{o}\left(1-a+\frac{a\left(\left(1-b P_{t h}\right)^{1-c}-\left(1+b\left(P-P_{t h}\right)\right)^{1-c}\right)}{b(c-1) P}\right)
$$


123 with the relation of the parameters $a, b$ and $c$ to the bulk modulus and its derivatives at zero

124 pressure (Freund and Ingalls, 1989):

125

$$
a=\frac{1+\kappa_{0}^{\prime}}{1+\kappa_{0}^{\prime}+\kappa_{0} \kappa_{o}^{\prime \prime}},
$$

126

$$
b=\frac{\kappa_{0}^{\prime}}{\kappa_{0}}-\frac{\kappa_{0}^{\prime \prime}}{1+\kappa_{0}^{\prime}}
$$

127

$$
c=\frac{1+\kappa_{0}^{\prime}+\kappa_{0} \kappa^{\prime \prime}}{\kappa_{0}^{\prime 2}+\kappa_{0}^{\prime}-\kappa_{0} \kappa_{o}^{\prime \prime}},
$$

128 where $\kappa_{0}$ is the bulk modulus at $298.15 \mathrm{~K}$ and $1 \mathrm{bar}$, and $\kappa_{0}^{\prime}$ and $\kappa_{0}^{\prime \prime}$ are the first and second

129 derivatives of $\kappa_{0} . \kappa_{0}, \kappa_{0}^{\prime}$ and $\kappa_{0}^{\prime \prime}$ have been provided by Holland and Powell (2011).

$$
P_{t h}=\alpha_{0} \kappa_{0} \frac{\theta}{\xi_{0}}\left(\frac{1}{e^{u}-1}-\frac{1}{e^{u_{0}}-1}\right)
$$

132 with $u=\theta / T$. Eq. (6) becomes

133

$$
P_{t h}=\alpha_{0} \kappa_{0} \frac{\theta}{\xi_{0}}\left(\frac{1}{e^{\frac{\theta}{T}}-1}-\frac{1}{e^{\frac{\theta}{T_{0}}}-1}\right)
$$

134 where $\alpha_{0}$ is the thermal expansion parameter, and

135

$$
\xi_{0}=\frac{u_{0}^{2} e^{u_{0}}}{\left(e^{u_{0}}-1\right)^{2}}=\frac{\left(\frac{\theta}{T_{0}}\right)^{2} e^{\frac{\theta}{T_{0}}}}{\left(e^{\frac{\theta}{T_{0}}}-1\right)^{2}}
$$


136 An empirical relationship for $\theta$ is derived for the substance of interest, $\theta_{i}=10636 /\left(S_{i} / n_{i}+6.44\right)$,

137 where $S_{i}$ is the molar entropy (in $\mathrm{J} \mathrm{K}^{-1} \mathrm{~mol}^{-1}$ ) of $i$ and $n_{i}$ is the number of atoms in the chemical

138 formula of $i$.

139 Different equations are used to represent the variation of mineral heat capacity with 140 temperature, but there are no differences in principle. SUPCRT92 (Johnson et al., 1992) uses the 141 Maier and Kelley (1932) equation,

$$
C_{p}=a+b T+c T^{-2}
$$

HP11, however, uses the heat capacity polynomial equation as in HP98, which is

$$
C_{p}=a+b T+c T^{-2}+d T^{-0.5}
$$

minerals listed in HP11 Table 2b) or Bragg-Williams type model (for minerals listed in HP11 Table 2c). We modified the SUPCRT92 codes to incorporate the Landau equations (see

149 Appendix 1) and added Landau parameters into the database. However, for minerals listed in HP11 Table 2c, Holland and Powell (2011) did not give sufficient details for us to program the Bragg-Williams type model, but HP98 treated phase transition for some of these minerals with Landau model and the Landau model parameters were provided. Therefore, we used the Landau model and parameters for these minerals. Four minerals in Table 2c: Ca-Tschermaks pyroxene,

154 sanidine, spinel, and hercynite have no Landau parameters in HP98 and picrochromite is new in 155 HP11. Currently, these five minerals have no phase transition provisions in the SUPCRTBL 156 package.

Figure 1 compares the standard molal heat capacity, entropy, enthalpy, and Gibbs free energy of formation for quartz, calculated with the Landau model (SUPCRTBL) and with HDNB 
159 phase transition approach (SUPCRT92). The Landau model simulates the phase transition of 160 quartz well. For $S_{T_{r}, P_{r}}^{\mathrm{o}}, \Delta_{f} H_{T_{r}, P_{r}}^{\mathrm{o}}, \Delta_{f} G_{T_{r}, P_{r}}^{\mathrm{o}}$, the Landau model produces smooth curves at phase

161 transition. Calculations using the Landau model for additional phases are shown in Appendix 1.

162 The $\Delta_{f} G_{T_{r}, P_{r}, i}^{o}$ values for minerals that are needed to incorporate the HP11 dataset into

163 our SUPCRTBL package, but they were not provided in HP11. We calculated $\Delta_{f} G_{T_{r}, P_{r}, i}^{o}$ values

164 for each mineral with formation from the elements at $298.15 \mathrm{~K}$ and 1 bar, i.e. the Benson-

165 Helgeson convention (Anderson, 2008). Standard molar entropy values for reference materials

166 were taken from CODATA (Cox et al., 1989) when possible to ensure the internal consistency

167 with other species in SUPCRTBL. For elements whose entropy values are not available in

168 CODATA (i.e., Fe and As), the entropy values were taken from Wagman et al. (1982). To verify

169 the calculations, $\Delta_{f} G_{T_{r}, P_{r}, i}^{o}$ values for minerals in HP98 were calculated with the same reference

170 materials and compared to published values. The differences were no more than rounding errors.

171

172

173 2.2. Updates for aqueous and mineral species of arsenic geochemistry

174 The interest in arsenic contamination in surface water and groundwater has greatly

175 increased in recent years due to an increased concern for public health. Therefore, reliable

176 thermodynamic data of arsenic is needed to perform speciation-solubility and sorption

177 calculations in order to improve our understanding of geochemical controls over the mobility of

178 arsenic (Welch et al., 2000). Unfortunately, as Nordstrom and Archer (2002) have pointed out,

179 most previous compilations are unreliable. They further provided an internally consistent

180 thermodynamic data set through simultaneous weighted least-squares multiple regressions on

181 thermochemical measurements. 
Thermodynamic data for ferric and ferrous bearing and barium bearing arsenate and

183 arsenite species, however, are unavailable in their compilation. We compiled a set of internally consistent thermodynamic properties for arsenic, as described in Lu and Zhu (2011). These thermodynamic properties consist of those from Nordstrom and Archer (2002) (Note: Only $25{ }^{\circ} \mathrm{C}$ values are available and some only have $\Delta G_{f, T_{r}, P_{r}}^{\circ}$ values), metal arsenic complexes recalculated from Marini and Accornero (2010), amorphous ferric arsenate and scorodite recalculated from Langmuir et al. (2006), and barium arsenate and barium hydrogen arsenate recalculated from Zhu et al. (2005). The compilation of the new data for arsenic-bearing species is listed in Table 1 and 2.

\section{Updates for aqueous and mineral species in the interest of geological carbon sequestration}

The injection of $\mathrm{CO}_{2}$ into deep saline aquifers is being considered as an option for greenhouse gas mitigation (IPCC, 2005). Four trapping mechanisms have been identified for the underground storage of $\mathrm{CO}_{2}$ : (1) structural and stratigraphic trapping; (2) residual $\mathrm{CO}_{2}$ trapping; (3) solubility trapping; and (4) mineral trapping (Bachu, 2008; IPCC, 2005). Reactive transport modeling (RTM) has been used to model the geochemical interactions of $\mathrm{CO}_{2}$-brine-host rock in order to understand the storage process, which is instrumental for evaluating the capacity and safety of the reservoir, and the fate of the injected $\mathrm{CO}_{2}$ (Andre et al., 2007; Johnson et al., 2004a;

Johnson et al., 2004b; Liu et al., 2011; Strazisar et al., 2006; Xu et al., 2004; Zhang et al., 2015; Zhu et al., in press). It is has been previously noted that the quality of the thermodynamic database used in the RTM contributes significantly to the inherent uncertainties in the modeling approach (IPCC, 2005). We have updated Al-bearing species, $\mathrm{SiO}_{2}{ }^{\circ}$ and $\mathrm{HSiO}_{3}{ }^{-}$, boehmite and 
205 206

207

208

209

210

211

212

213

214

215

216

217

218

219

220

221

222

223

224

225

226

227

gibbsite to improve the modeling of aluminosilicate reactions and dawsonite for the mineral carbonation.

Thermodynamic properties for aqueous $\mathrm{Al}$ species $\left(\mathrm{Al}^{3+}, \mathrm{Al}(\mathrm{OH})_{2}{ }^{+}, \mathrm{AlOH}{ }^{2+}, \mathrm{Al}(\mathrm{OH})_{4}\right.$, $\left.\mathrm{Al}(\mathrm{OH})_{3}(\mathrm{aq}), \mathrm{NaAl}(\mathrm{OH})_{4}(\mathrm{aq}), \mathrm{AlH}_{3} \mathrm{SiO}_{4}{ }^{2+}\right)$ have been evaluated and discussed in $\mathrm{Zhu}$ and $\mathrm{Lu}$ (2009). We adopted the properties from Tagirov and Schott (2001). It should be mentioned that the thermodynamic properties for Al-bearing species in sprons96.dat are from Pokrovskii and Helgeson (1995) while those in slop98.dat and slop07.dat are from Shock et al. (1997b). Data in Pokrovskii and Helgeson (1995) yield predictions of boehmite solubility at $250{ }^{\circ} \mathrm{C}$ to $350{ }^{\circ} \mathrm{C}$ in weakly acid and near-neutral solutions $~ 1.5$ order of magnitude higher than experimental results and this inconsistency increases with temperature (Tagirov and Schott, 2001).

Thermodynamic properties of species $\mathrm{SiO}_{2}{ }^{\circ}(\mathrm{aq})$ in the earlier versions of SUPCRT92 are from Shock et al. (1997b). These properties have long been somewhat controversial, especially at temperatures near $25{ }^{\circ} \mathrm{C}$ (Tutolo et al., 2014). Rimstidt (1997) performed a new set of quartz solubility experiments in the range of $21{ }^{\circ} \mathrm{C}$ to $96{ }^{\circ} \mathrm{C}$, the duration of which were up to 4917 days. These experiments yielded quartz solubility that are higher than earlier studies, and were selected by Apps and Spycher (2004) and by Gunnarsson and Arnórsson (2000) for re-evaluation standard state partial molal properties for $\mathrm{SiO}_{2}{ }^{\circ}(\mathrm{aq})$ and $\mathrm{H}_{4} \mathrm{SiO}_{4}{ }^{\circ}$ (aq), respectively. In the SUPCRTBL database, we retained the values for $\mathrm{SiO}_{2}{ }^{\circ}(\mathrm{aq})$ from Apps and Spycher (2004) and also those for $\mathrm{H}_{4} \mathrm{SiO}_{4}{ }^{\circ}$ (aq) from Stefansson (2001). Stefansson (2001) derived standard molal properties for $\mathrm{H}_{4} \mathrm{SiO}_{4}{ }^{\circ}$ (aq) from quartz and amorphous solubility data by using the Gibbs free energy data for quartz from HDNB. HP11 and HDNB practically use the same value of $\Delta_{f} G_{T_{r}, P_{r}}^{o}$ for quartz (856.24 and $-856.28 \mathrm{KJ} / \mathrm{mol}$, respectively). Therefore, we consider the quartz and aqueous silica values are consistent. Thermodynamic properties of $\mathrm{HSiO}_{3}{ }^{-}$were then 
228 calculated taking account of the change of the properties of $\mathrm{SiO}_{2}{ }^{\circ}(\mathrm{aq})$, using the difference in

229 Shock et al. (1997b).

The only aluminum oxyhydroxide mineral listed in the Holland and Powell (2011)

231 database is diaspore, because it is the stable phase at the $T, P$ of petrological interest. Boehmite

232 and gibbsite, however, are two other common minerals often found in experiments and in nature

233 at lower temperatures. Therefore, their thermodynamic properties need to be added into the new

234 database. We adopted the heat capacity, entropy, and enthalpy of formation for boehmite from

235 Hemingway et al. (1991). We also examined the consistency of these thermodynamic properties

236 with the rest of Holland and Powell (2011) carefully following the method of Zhu and Lu (2009).

$237 C_{p}$ data was fitted to the Holland and Powell $C_{p}$ function $\left(C_{p}=a+b T+c T^{2}+d T^{0.5}\right)$.

238 For gibbsite, we followed the same procedure as boehmite. To date, most gibbsite

239 solubility data in the literature has been calculated based on the thermodynamic properties from

240 Robie et al. (1978), which are based on heat of dissolution and heat capacity measurements

241 reported in Hemingway et al. (1977), Hemingway et al. (1978) and Hemingway et al. (1977).

242 Gibbsite data in Tagirov and Schott (2001), for example, is from Robie et al. (1978), with the

243 heat capacity given in Wesolowski (1992). The data in Robie et al. (1978) is cited by Robie and

244 Hemingway (1995) and the source of the data in Wesolowski (1992) is Hemingway et al. (1977).

245 Therefore, we adopted the thermodynamic properties from Robie et al. (1978), and then

246 conducted non-linear fitting of $C_{p}$ data to the Holland and Powell $C_{p}$ function $\left(C_{p}=a+b T+c T^{2}+\right.$

$\left.247 d T^{0.5}\right)$. The Holland and Powell coefficients $\left(a, b\left(10^{5}\right), c\right.$ and $\left.d\right)$ are 0.092797, 18.943789,

248133.865406 and -1.034267 (in kJ, mol and K), respectively.

A considerable amount of RTM modeling results indicate that the injection of $\mathrm{CO}_{2}$ into deep sedimentary formations will lead to the formation of various carbonate minerals, including 
251 dawsonite. The thermodynamic properties for dawsonite, however, are limited and this is

252 indicative of considerable obstacles for $\mathrm{CO}_{2}$ sequestration modeling. The thermodynamic

253 properties of dawsonite were derived from previous experimental measurements in the present

254 study in order to reduce the uncertainty during the modeling.

Ferrante et al. (1976) determined the thermodynamic properties of synthetic dawsonite

256 from a series of calorimetric studies. Employing the heat capacities determined from 6 to $307 \mathrm{~K}$

257 in their study, the $\mathrm{Cp}$ coefficients of dawsonite were derived according to the Holland-Powell Cp

258 equation (i.e., $\mathrm{C} p=a+b T+c T^{2}+d T^{0.5}$ ) by least-squares regression. The resulted Holland and

259 Powell Cp coefficients $\left(a, b\left(10^{5}\right), c\right.$ and $\left.d\right)$ are 0.009553, 48.643184, 1.062736, and -0.088676

260 (in kJ, mol and K), respectively. Recently, Benezeth et al. (2007) measured the solubility of

261 synthetic dawsonite according to the equilibrium:

262

$$
\mathrm{NaAlCO}_{3}(\mathrm{OH})_{2}+2 \mathrm{H}_{2} \mathrm{O}=\mathrm{Al}(\mathrm{OH})_{4}{ }^{-}+\mathrm{HCO}_{3}{ }^{-}+\mathrm{Na}^{+}+\mathrm{H}^{+}
$$

263 at $50-200^{\circ} \mathrm{C}$. Additionally, $\Delta G_{r}^{\circ} T r, P r, \Delta H_{r}^{\circ} \operatorname{Tr}, \operatorname{Pr}$ and $S_{r}^{\circ} \operatorname{Tr}, \operatorname{Pr}$ were calculated in their study, which

264 were $102.1 \mathrm{~kJ} / \mathrm{mol}, 97.0 \mathrm{~kJ} / \mathrm{mol}$, and $-17.1 \mathrm{~kJ} / \mathrm{mol} / \mathrm{K}$, respectively. Combining the reported $\Delta G_{r}{ }^{\circ}$,

$265 \Delta H_{r}{ }^{\circ}$ and $S_{r}{ }^{\circ}$ values, with the thermodynamic properties of $\mathrm{Al}(\mathrm{OH})_{4}{ }^{-}, \mathrm{HCO}_{3}{ }^{-}, \mathrm{Na}^{+}$and $\mathrm{H}_{2} \mathrm{O}$ in

266 SUPCRTBL database, we were able to derive a set of $\Delta_{f} G_{T r, P r}^{\mathrm{o}}, \Delta_{f} H^{\mathrm{o}}{ }_{T r, P r}, S^{\mathrm{o}}{ }_{T r}, P r$ for dawsonite

267 that are internally consistent with our own database (Table 3). As seen in Table 2, the retrieved

$268 \Delta_{f} G^{\mathrm{o}} \operatorname{Tr}, \operatorname{Pr}$ value was similar to the data derived in Benezeth et al. (2007). The SUPCRTBL

269 calculations with derived thermodynamic data can fit the laboratory measurements fairly well

270 (Fig 2).

271

272 4. Updates of the SUPCRT92 Code 
We made four major modifications to the source code of SUPCRT92. The first

274

275

276

277

278

279

280

281

282

283

modification was to implement the heat capacity polynomial equations and volume function from Holland and Powell (2011) into the code. The code of CPRONS92 was modified to take into account the updated format of the database and re-named into CPRONSBL (see supplement material for the exact line by line list of major modifications.). CPRONS92 is the program that converts the code of a sequential access file to a direct access file that SUPCRT92 can read. The update to the database included six new properties for each mineral: $d$ (the fourth heat capacity variable), $\alpha, \kappa_{0}, \kappa_{0}^{\prime}, \kappa_{0}^{\prime \prime}$ and the number of atoms in its chemical formula. Figure 3 shows an example of updated data block of forsterite. Likewise, the maximum size of the input sequential access file was increased from 10,000 lines to 1,000,000 lines to accommodate the expansion in size of the input file.

Second, the code of SUPCRT92 was modified in three different files, REAC.for, REP.for and SUPCRT.for (See supplement material for the exact line by line list of major modifications). In all of these files, the maximum amount of reaction parameter was adjusted from 50 to 3000 and the maximum increments for uniform and non-uniform tables was reduced from 75 to 21 in order to facilitate the database generation by batch calculations. To update the heat capacity equations, the code in the procedures Cptrms, Cp, CpdT, CpdlnT in REAC.for were also changed (Fig. 4).

For the changes to the mineral volume equations, only the Vterms procedure in REAC.for was modified with the new volume contribution to the Gibbs free energy equation (Fig. 5).

Third, the HP11 dataset has a drastically different approach from HDNB to calculate thermodynamic properties related to phase transition and order - disorder. SUPCRT92 divided 
296 minerals according to the number of phase transitions, and different heat capacity functions for

297 phases above and below the temperature of phase transition are used. HP11 uses the Landau

298 theory approach, which was programmed into SUPCRTBL. The details are given in Appendix 1.

299 The fourth major change is that we no longer use calories and have adopted joules for all 300 properties in the database and output files. The rest of the changes made to SUPCRT92 were to

301 enable the reading of the new database into the data structures and variables used by the 302 program.

303

304 5. Example Calculations

305 Rimstidt (1997) conducted quartz dissolution experiments at temperatures from 21 to 96

$306{ }^{\circ} \mathrm{C}$, evaluated quartz solubility data in literature at temperature from 0 to $370{ }^{\circ} \mathrm{C}$, and determined

307 the Gibbs free energy of formation and entropy for $\mathrm{SiO}_{2}{ }^{\circ}(\mathrm{aq})$. From the solubility data, Rimstidt

308 (1997) used standard thermodynamic properties for quartz and water from Robie and

309 Hemingway (1995) to derive the standard thermodynamic properties for $\mathrm{H}_{4} \mathrm{SiO}_{4}{ }^{\mathrm{O}}(\mathrm{aq})$.

310 Quartz $+2 \mathrm{H}_{2} \mathrm{O}=\mathrm{H}_{4} \mathrm{SiO}_{4, a q}$

311 The $\log K$ of this reaction was calculated using this updated SUPCRTBL, and then was

312 converted to quartz solubility based on the following equation, which is valid at low ionic

313 strength solution.

$314 \log K=\log \left(\frac{a_{\mathrm{SiO}_{2}, a q}}{a_{\text {Quartz }}}\right)=\log \left(\frac{m_{\mathrm{SiO}_{2}, a q}}{1}\right)=\log m_{\mathrm{SiO}_{2}, a q}$ 
where $K$ is the equilibrium constant, $a_{\mathrm{i}}$ is the activity of species $\mathrm{i}, m_{\mathrm{i}}$ is the molality of species $\mathrm{i}$

(mol/kg). $a_{\mathrm{SiO} 2, \mathrm{aq}}=\sim m_{\mathrm{SiO} 2, \mathrm{aq}}$ in low salinity solution, and $a_{\mathrm{Quartz}}$ is 1 .

The thermodynamic properties of aqueous silica $\left(\mathrm{SiO}_{2}, \mathrm{aq}\right)$ (enthalpy and entropy) and HKF parameters $c_{1}, c_{2}$, and $\omega$ are fitted by Xu et al. (2004) using HKF model based on the experimental data that Rimstidt (1997) compiled. Four HKF volume parameters $a_{1}$ to $a_{4}$ are from slop07.dat. Stefansson (2001) also evaluated the quartz and amorphous silica solubility data and derived standard molal properties and HKF parameters for $\mathrm{H}_{4} \mathrm{SiO}_{4}{ }^{\circ}$ (aq).

With these values, we calculated the solubility of quartz at 10 to $370{ }^{\circ} \mathrm{C}$ with various datasets, and compare them with the experimental data evaluated by Rimstidt (1997). Figure 6 shows the experimental data compiled by Rimstidt (1997) and the calculated values using the updated SUPCRTBL as well as results using slop07.dat and other models for comparison.

To verify the volume calculations in SUPCRTBL, we compared calculated stishovite molal volume as a function of pressure up to 2000 kbars to those in HP 11 in Fig 7. Our calculated values overlap with those calculations in HP 11's Fig 4. To verify the Gibbs free energy calculations, we calculated the univariant phase boundary for Mg-ringwoodite and Mgwadsleyite in the temperature range of $800-1800{ }^{\circ} \mathrm{C}$ and pressure range of $160-\sim 200$ kbars. Our calculated values overlap with those in HP 11 (Fig. 8)

\section{Conclusions and Remarks}

There is little doubt that the development of SUPCRT92 software package and affiliated thermodynamic datasets has greatly contributed for making geochemical calculations highly efficient and improving our understanding of geochemical systems. Built on these successes, we have modified the dataset for SUPCRT92. The thermodynamic properties of some aqueous 
337 species and minerals have been updated, which include Al-bearing aqueous and mineral phases,

338 As-bearing aqueous and mineral phases, $\mathrm{SiO}_{2}{ }^{\circ}(\mathrm{aq}), \mathrm{HSiO}_{3}{ }^{-}$and dawsonite. The modifications are

339 in line with new needs and interests of metamorphic petrology, economic geology, arsenic

340 geochemistry, and carbon management. Table 4 compares the updates from this study with

341 previous efforts of updating slop98.dat.

342 There are still many limitations and uncertainties with this dataset, however. The

343 development of thermodynamic databases for the modeling of geochemical processes is an

344 ongoing process. We need to continuously identify species with incorrect information and

345 develop new equations and algorithms. Because of this need, we are compiling a relational

346 database in order to make update thermodynamic data and the program easier. The program,

347 dataset, updates, and corrections can be found at www.indiana.edu/ hydrogeo/SUPCRT

\section{6. Acknowledgements}

350 This work was built upon SUPCRT92 developed and published by Jim Johnson, Eric Oelkers, 351 and Harold Helgeson. SUPCRT92 has served well the geochemistry community for more than

352 two decades. We hope that our modifications continue to ensure that their contribution continues 353 to be in use for many years to come. CZ acknowledges U.S. NSF grant EAR-1225733 and the

354 U.S. Department of Energy grant DE-FE000438. Although the work was partly sponsored by an 355 agency of the United States Government, the views and opinions of authors expressed herein do 356 not necessarily state or reflect those of the United States Government or any agency thereof. We 357 thank Jim Palandri for providing an earlier version of SUPCRT92 that includes the HP98 mineral 358 data. We also wish to thank Tim Holland and Roger Powell for their assistance in the calculation 
359 of the updated volume term. We are also grateful for the financial support from China 360 Scholarship Council for GRZ.

361 
Table 1. Thermodynamic properties for As-bearing aqueous species

\begin{tabular}{|c|c|c|c|c|c|c|c|c|c|c|c|c|c|}
\hline Species & $\begin{array}{l}\Delta_{f} G_{T r, P r}^{o} \\
(\mathbf{k J} / \mathbf{m o l})\end{array}$ & $\begin{array}{l}\Delta_{f} H^{o} T r, P r \\
(\mathbf{k J} / \mathbf{m o l})\end{array}$ & $\begin{array}{l}S_{T r, P r}^{o} \\
(\mathrm{~J} / \mathrm{mol} / \mathbf{K})\end{array}$ & $\begin{array}{l}C_{p, T r, P r} \\
(\mathrm{~J} / \mathrm{mol} / \mathbf{K})\end{array}$ & $\begin{array}{l}V_{T r, P r}^{o} \\
\text { (J/bar) }\end{array}$ & $\begin{array}{l}a_{1} \times 10 \\
(\mathrm{~kJ} / \mathrm{mol} / \\
\text { bar) }\end{array}$ & $\begin{array}{l}a_{2} \times 10^{-2} \\
(\mathrm{~kJ} / \mathrm{mol})\end{array}$ & $\begin{array}{l}a_{3} \\
(\mathrm{~kJ} / \mathrm{K} / \mathrm{mol} \\
\text { /bar) } \\
\end{array}$ & $\begin{array}{l}a_{4} \times 10^{-4} \\
(\mathrm{~kJ} / \mathrm{K} / \\
\mathrm{mol})\end{array}$ & $\begin{array}{l}c_{1} \\
(\mathbf{k J} / \mathrm{mol} / \\
\mathrm{K}) \\
\end{array}$ & $\begin{array}{l}c_{2} \times 10^{-4} \\
(\mathrm{~kJ} \cdot \mathrm{K} / \\
\mathrm{mol})\end{array}$ & $\begin{array}{l}\omega \times 10^{-5} \\
(\mathrm{~kJ} / \mathrm{mol})\end{array}$ & Ref \\
\hline $\mathrm{H}_{3} \mathrm{AsO}_{4}{ }^{\mathrm{O}}$ & -766.75 & -903.45 & 183.05 & & & & & & & & & & 1 \\
\hline $\mathrm{H}_{2} \mathrm{AsO}_{4}^{-}$ & -753.65 & -911.42 & 112.38 & & & & & & & & & & 1 \\
\hline $\mathrm{HAsO}_{4}{ }^{2-}$ & -713.73 & -908.41 & -11.42 & & & & & & & & & & 1 \\
\hline $\mathrm{AsO}_{4}{ }^{3-}$ & -646.36 & -890.21 & -176.31 & & & & & & & & & & 1 \\
\hline $\mathrm{H}_{3} \mathrm{AsO}_{3}{ }^{\circ}$ & -639.80 & -742.36 & 195.81 & & & & & & & & & & 1 \\
\hline $\mathrm{H}_{2} \mathrm{AsO}_{3}^{-}$ & -587.66 & -714.74 & 112.80 & & & & & & & & & & 1 \\
\hline $\mathrm{HAsO}_{3}{ }^{2-}$ & -507.40 & & & & & & & & & & & & 1 \\
\hline $\mathrm{AsO}_{3}{ }^{3-}$ & -421.80 & & & & & & & & & & & & 1 \\
\hline $\mathrm{As}_{3} \mathrm{~S}_{4}(\mathrm{HS})_{2}^{-}$ & -125.60 & & & & & & & & & & & & 1 \\
\hline $\mathrm{AsS}(\mathrm{OH}) \mathrm{SH}^{-}$ & -244.40 & & & & & & & & & & & & 1 \\
\hline $\mathrm{NaH}_{2} \mathrm{AsO}_{4}{ }^{\circ}$ & -1004.91 & -1140.59 & 172.38 & 158.16 & 4.11 & 0.03087 & 0.04282 & 0.00478 & -0.01340 & 0.11682 & 0.01951 & -0.00016 & 2 \\
\hline $\mathrm{KH}_{2} \mathrm{AsO}_{4}{ }^{\circ}$ & -1024.81 & -1147.89 & 228.03 & 91.63 & 5.24 & 0.03735 & 0.05867 & -0.00203 & -0.01405 & 0.07787 & 0.00593 & -0.00016 & 2 \\
\hline $\mathrm{MgH}_{2} \mathrm{AsO}_{4}^{+}$ & -1217.17 & -1392.09 & -43.51 & 212.13 & 1.83 & 0.01887 & 0.01353 & 0.01736 & -0.01219 & 0.17684 & 0.03050 & 0.00293 & 2 \\
\hline $\mathrm{CaH}_{2} \mathrm{AsO}_{4}^{+}$ & -1314.49 & -1456.06 & 77.40 & 191.63 & 2.22 & 0.02048 & 0.01746 & 0.01567 & -0.01235 & 0.14794 & 0.02630 & 0.00110 & 2 \\
\hline $\mathrm{SrH}_{2} \mathrm{AsO}_{4}^{+}$ & -1321.71 & -1455.37 & 114.22 & 167.78 & 2.29 & 0.02071 & 0.01801 & 0.01543 & -0.01237 & 0.12893 & 0.02147 & 0.00054 & 2 \\
\hline $\mathrm{MnH}_{2} \mathrm{AsO}_{4}^{+}$ & -989.44 & -1133.14 & 60.67 & 223.84 & 2.33 & 0.02118 & 0.01916 & 0.01494 & -0.01242 & 0.16914 & 0.03288 & 0.00136 & 2 \\
\hline $\mathrm{FeH}_{2} \mathrm{AsO}_{4}^{+}$ & -860.62 & -1019.72 & 4.18 & 187.86 & 1.76 & 0.01821 & 0.01192 & 0.01805 & -0.01212 & 0.15610 & 0.02559 & 0.00221 & 2 \\
\hline $\mathrm{CoH}_{2} \mathrm{AsO}_{4}^{+}$ & -809.14 & -972.18 & -6.28 & 189.12 & 1.39 & 0.01616 & 0.00691 & 0.02020 & -0.01191 & 0.15812 & 0.02578 & 0.00237 & 2 \\
\hline $\mathrm{NiH}_{2} \mathrm{AsO}_{4}{ }^{+}$ & -808.12 & -978.16 & -29.71 & 152.30 & 1.00 & 0.01405 & 0.00175 & 0.02241 & -0.01170 & 0.13995 & 0.01831 & 0.00273 & 2 \\
\hline $\mathrm{CuH}_{2} \mathrm{AsO}_{4}^{+}$ & -698.17 & -855.13 & 17.15 & 208.78 & 1.49 & 0.01662 & 0.00802 & 0.01972 & -0.01196 & 0.16639 & 0.02981 & 0.00201 & 2 \\
\hline $\mathrm{ZnH}_{2} \mathrm{AsO}_{4}^{+}$ & -903.44 & -1068.48 & -1.26 & 212.13 & 1.53 & 0.01690 & 0.00872 & 0.01942 & -0.01199 & 0.17102 & 0.03052 & 0.00229 & 2 \\
\hline $\mathrm{PbH}_{2} \mathrm{AsO}_{4}^{+}$ & -786.16 & -901.97 & 187.02 & 142.67 & 2.50 & 0.02149 & 0.01992 & 0.01461 & -0.01245 & 0.10422 & 0.01639 & -0.00056 & 2 \\
\hline $\mathrm{AlH}_{2} \mathrm{AsO}_{4}{ }^{2+}$ & -1255.11 & -1467.40 & -238.49 & 146.02 & -0.71 & 0.00606 & -0.01776 & 0.03079 & -0.01089 & 0.18636 & 0.01703 & 0.00816 & 2 \\
\hline $\mathrm{FeH}_{2} \mathrm{AsO}_{4}{ }^{2+}$ & -794.75 & -985.48 & -166.94 & 276.98 & 0.11 & 0.01042 & -0.00712 & 0.02622 & -0.01133 & 0.25287 & 0.04368 & 0.00708 & 2 \\
\hline $\mathrm{NaHAsO}_{4}^{-}$ & -979.16 & -1141.97 & 81.17 & 46.02 & 1.64 & 0.01868 & 0.01305 & 0.01756 & -0.01217 & 0.10401 & -0.00331 & 0.00555 & 2 \\
\hline $\mathrm{KHAsO}_{4}^{-}$ & -998.95 & -1151.63 & 128.45 & 16.32 & 2.61 & 0.02397 & 0.02597 & 0.01201 & -0.01270 & 0.08010 & -0.00934 & 0.00484 & 2 \\
\hline $\mathrm{MgHAsO}_{4}{ }^{\circ}$ & -1182.63 & -1365.89 & -71.55 & -14.23 & -0.05 & 0.00706 & -0.01531 & 0.02974 & -0.01099 & 0.01618 & -0.01558 & -0.00016 & 2 \\
\hline $\mathrm{CaHAsO}_{4}{ }^{\mathrm{O}}$ & -1280.46 & -1440.72 & 14.64 & -23.43 & 0.20 & 0.00846 & -0.01189 & 0.02827 & -0.01114 & 0.01083 & -0.01744 & -0.00016 & 2 \\
\hline $\mathrm{SrHAsO}_{4}{ }^{\mathrm{O}}$ & -1287.63 & -1443.13 & 41.00 & -33.89 & 0.24 & 0.00872 & -0.01126 & 0.02800 & -0.01116 & 0.00467 & -0.01959 & -0.00016 & 2 \\
\hline $\mathrm{MnHAsO}_{4}{ }^{\circ}$ & -960.50 & -1121.45 & 2.93 & -8.79 & 0.27 & 0.00885 & -0.01095 & 0.02787 & -0.01117 & 0.01921 & -0.01452 & -0.00016 & 2 \\
\hline $\mathrm{FeHAsO}_{4}{ }^{\circ}$ & -824.08 & -995.62 & -37.24 & -24.69 & -0.09 & 0.00680 & -0.01595 & 0.03001 & -0.01097 & 0.00992 & -0.01776 & -0.00016 & 2 \\
\hline $\mathrm{CoHAsO}_{4}{ }^{\circ}$ & -784.57 & -959.14 & -44.77 & -24.27 & -0.32 & 0.00548 & -0.01918 & 0.03140 & -0.01083 & 0.01017 & -0.01767 & -0.00016 & 2 \\
\hline $\mathrm{NiHAsO}_{4}{ }^{\mathrm{O}}$ & -774.39 & -953.93 & -61.50 & -40.58 & -0.57 & 0.00408 & -0.02260 & 0.03287 & -0.01069 & 0.00063 & -0.02100 & -0.00016 & 2 \\
\hline $\mathrm{CuHAsO}_{4}{ }^{\circ}$ & -669.62 & -840.13 & -28.03 & -15.48 & -0.26 & 0.00584 & -0.01830 & 0.03102 & -0.01087 & 0.01530 & -0.01588 & -0.00016 & 2 \\
\hline $\mathrm{ZnHAsO}_{4}{ }^{\circ}$ & -877.92 & -1054.90 & -41.42 & -14.23 & -0.24 & 0.00596 & -0.01800 & 0.03089 & -0.01088 & 0.01621 & -0.01557 & -0.00016 & 2 \\
\hline $\mathrm{PbHAsO}_{4}{ }^{\circ}$ & -753.62 & -897.51 & 92.88 & -44.77 & 0.37 & 0.00945 & -0.00949 & 0.02724 & -0.01124 & -0.00181 & -0.02185 & -0.00016 & 2 \\
\hline $\mathrm{AlHAsO}_{4}^{+}$ & -1237.98 & -1436.69 & -192.88 & -156.06 & -0.82 & 0.00442 & -0.02176 & 0.03251 & -0.01073 & -0.01741 & -0.04449 & 0.00520 & 2 \\
\hline $\mathrm{FeHAsO}_{4}^{+}$ & -787.38 & -971.57 & -145.18 & -97.93 & -0.49 & 0.00609 & -0.01770 & 0.03076 & -0.01090 & 0.00992 & -0.03264 & 0.00447 & 2 \\
\hline $\mathrm{NaAsO}_{4}{ }^{2-}$ & -935.96 & -1062.50 & 202.92 & -160.67 & -1.70 & 0.00118 & -0.02968 & 0.03591 & -0.01040 & 0.02863 & -0.04546 & 0.01050 & 2 \\
\hline
\end{tabular}




\begin{tabular}{|c|c|c|c|c|c|c|c|c|c|c|c|c|c|}
\hline $\mathrm{KAsO}_{4}{ }^{2-}$ & -955.74 & -1042.02 & 351.46 & -190.37 & -0.96 & 0.00465 & -0.02120 & 0.03227 & -0.01075 & -0.00938 & -0.05149 & 0.00825 & 2 \\
\hline $\mathrm{MgAsO}_{4}^{-}$ & -1135.85 & -1285.81 & 40.33 & -230.12 & -2.60 & -0.00540 & -0.04576 & 0.04281 & -0.00974 & -0.05159 & -0.05954 & 0.00617 & 2 \\
\hline $\mathrm{CaAsO}_{4}^{-}$ & -1233.92 & -1351.91 & 156.48 & -239.32 & -2.55 & -0.00572 & -0.04654 & 0.04315 & -0.00970 & -0.07315 & -0.06141 & 0.00441 & 2 \\
\hline $\mathrm{SrAsO}_{4}^{-}$ & -1239.48 & -1352.43 & 183.68 & -249.78 & -2.54 & -0.00581 & -0.04676 & 0.04324 & -0.00969 & -0.08312 & -0.06356 & 0.00400 & 2 \\
\hline $\mathrm{MnAsO}_{4}^{-}$ & -913.32 & -1036.82 & 128.45 & -224.68 & -2.54 & -0.00551 & -0.04601 & 0.04292 & -0.00973 & -0.06085 & -0.05849 & 0.00484 & 2 \\
\hline $\mathrm{FeAsO}_{4}^{-}$ & -781.02 & -914.38 & 90.79 & -240.58 & -2.61 & -0.00571 & -0.04652 & 0.04314 & -0.00970 & -0.06487 & -0.06172 & 0.00541 & 2 \\
\hline $\mathrm{CoAsO}_{4}^{-}$ & -741.36 & -880.65 & 73.64 & -240.16 & -2.65 & -0.00589 & -0.04695 & 0.04332 & -0.00969 & -0.06223 & -0.06164 & 0.00567 & 2 \\
\hline $\mathrm{NiAsO}_{4}^{-}$ & -737.66 & -884.16 & 49.37 & -256.48 & -2.70 & -0.00604 & -0.04731 & 0.04348 & -0.00967 & -0.06837 & -0.06496 & 0.00604 & 2 \\
\hline $\mathrm{CuAsO}_{4}^{-}$ & -634.89 & -768.21 & 96.65 & -231.38 & -2.64 & -0.00593 & -0.04705 & 0.04337 & -0.00968 & -0.06032 & -0.05985 & 0.00532 & 2 \\
\hline $\mathrm{ZnAsO}_{4}^{-}$ & -837.31 & -978.44 & 79.08 & -230.12 & -2.64 & -0.00582 & -0.04678 & 0.04325 & -0.00969 & -0.05695 & -0.05953 & 0.00559 & 2 \\
\hline $\mathrm{PbAsO}_{4}^{-}$ & -710.41 & -813.52 & 229.70 & -260.66 & -2.52 & -0.00590 & -0.04698 & 0.04334 & -0.00969 & -0.09599 & -0.06582 & 0.00331 & 2 \\
\hline $\mathrm{AlAsO}_{4}{ }^{\circ}$ & -1194.77 & -1380.77 & -150.21 & -251.88 & -0.98 & 0.00175 & -0.02829 & 0.03531 & -0.01046 & -0.12277 & -0.06402 & -0.00016 & 2 \\
\hline $\mathrm{FeAsO}_{4}{ }^{\mathrm{o}}$ & -744.17 & -914.40 & -98.32 & -354.80 & -1.31 & -0.00016 & -0.03296 & 0.03732 & -0.01026 & -0.18291 & -0.08499 & -0.00016 & 2 \\
\hline $\mathrm{NaH}_{2} \mathrm{AsO}_{3}{ }^{\circ}$ & -850.48 & -957.43 & 166.10 & 118.83 & 3.27 & 0.02604 & 0.03104 & 0.00984 & -0.01291 & 0.09386 & 0.01150 & -0.00016 & 2 \\
\hline $\mathrm{AgH}_{2} \mathrm{AsO}_{3}{ }^{\mathrm{o}}$ & -516.83 & -615.35 & 185.35 & 107.95 & 3.30 & 0.02624 & 0.03152 & 0.00963 & -0.01293 & 0.08748 & 0.00928 & -0.00016 & 2 \\
\hline $\mathrm{MgH}_{2} \mathrm{AsO}_{3}{ }^{+}$ & -1051.90 & -1197.39 & -47.28 & 172.80 & 0.99 & 0.01407 & 0.00179 & 0.02240 & -0.01170 & 0.15442 & 0.02250 & 0.00299 & 2 \\
\hline $\mathrm{CaH}_{2} \mathrm{AsO}_{3}^{+}$ & -1150.27 & -1263.03 & 71.55 & 152.30 & 1.38 & 0.01568 & 0.00574 & 0.02070 & -0.01186 & 0.12582 & 0.01830 & 0.00119 & 2 \\
\hline $\mathrm{SrH}_{2} \mathrm{AsO}_{3}^{+}$ & -1153.11 & -1258.14 & 107.95 & 128.45 & 1.45 & 0.01591 & 0.00630 & 0.02046 & -0.01189 & 0.10688 & 0.01347 & 0.00064 & 2 \\
\hline $\mathrm{BaH}_{2} \mathrm{AsO}_{3}^{+}$ & -1156.10 & -1246.56 & 167.78 & 107.11 & 1.99 & 0.01867 & 0.01305 & 0.01756 & -0.01217 & 0.08616 & 0.00915 & -0.00026 & 2 \\
\hline $\mathrm{CuH}_{2} \mathrm{AsO}_{3}{ }^{+}$ & -562.20 & -690.04 & 12.55 & 169.45 & 0.65 & 0.01181 & -0.00371 & 0.02476 & -0.01147 & 0.14412 & 0.02181 & 0.00209 & 2 \\
\hline $\mathrm{PbH}_{2} \mathrm{AsO}_{3}^{+}$ & -640.73 & -728.28 & 179.08 & 103.34 & 1.65 & 0.01670 & 0.00823 & 0.01963 & -0.01197 & 0.08235 & 0.00838 & -0.00044 & 2 \\
\hline $\mathrm{AlH}_{2} \mathrm{AsO}_{3}^{+}$ & -1115.50 & -1295.42 & -232.21 & 106.69 & -1.56 & 0.00121 & -0.02962 & 0.03588 & -0.01040 & 0.16257 & 0.00902 & 0.00807 & 2 \\
\hline $\mathrm{FeH}_{2} \mathrm{AsO}_{3}{ }^{+}$ & -645.98 & -805.06 & -163.59 & 237.65 & -0.73 & 0.00557 & -0.01895 & 0.03130 & -0.01084 & 0.22941 & 0.03568 & 0.00703 & 2 \\
\hline
\end{tabular}


Table 2. Thermodynamic properties for As-bearing solids

\begin{tabular}{|c|c|c|c|c|}
\hline Species & $\begin{array}{l}\Delta_{f} G_{T r, P r}^{o} \\
(\mathbf{k J} / \mathbf{m o l})\end{array}$ & $\begin{array}{l}\Delta_{f} H^{o}{ }_{T r, P r} \\
(\mathbf{k J} / \mathbf{m o l})\end{array}$ & $\begin{array}{l}S_{T r, P r}^{o} \\
(\mathrm{~J} / \mathrm{mol} / \\
\mathrm{K})\end{array}$ & Ref. \\
\hline $\operatorname{As}(\alpha)$ & 0 & 0 & 35.63 & 1 \\
\hline $\mathrm{As}_{2} \mathrm{O}_{3}$ (Arsenolite) & -576.34 & -657.27 & 107.38 & 1 \\
\hline $\mathrm{As}_{2} \mathrm{O}_{3}$ (Claudetite) & -576.53 & -655.67 & 113.37 & 1 \\
\hline $\mathrm{As}_{2} \mathrm{O}_{5}$ & -774.76 & -917.59 & 105.44 & 1 \\
\hline $\operatorname{AsS}(\alpha$-Realgar $)$ & -31.30 & -31.80 & 62.90 & 1 \\
\hline $\operatorname{AsS}(\beta$, Realgar) & -30.90 & -31.00 & 63.50 & 1 \\
\hline $\mathrm{As}_{2} \mathrm{~S}_{3}$ (Orpiment) & -84.90 & -85.80 & 163.80 & 1 \\
\hline $\mathrm{As}_{2} \mathrm{~S}_{3}$ (Orpiment, am) & -76.80 & -66.90 & 200.00 & 1 \\
\hline FeAsS(Arsenopyrite) & -141.60 & & & 2 \\
\hline $\mathrm{FeAsO}_{4}: 2 \mathrm{H}_{2} \mathrm{O}$ (Scorodite) & -1287.08 & & & 3 \\
\hline $\mathrm{FeAsO}_{4}: 2 \mathrm{H}_{2} \mathrm{O}$ (Ferric-As,am) & -1270.98 & & & 3 \\
\hline $\mathrm{Ba}_{3}\left(\mathrm{AsO}_{4}\right)_{2}$ (Barium-As) & -3095.11 & & & 4 \\
\hline $\mathrm{BaHAsO}_{4}: \mathrm{H}_{2} \mathrm{O}($ Barium-H-As) & -1538.65 & & & 4 \\
\hline
\end{tabular}

${ }^{1}$ Nordstrom and Archer (2002). ${ }^{2}$ Ball and Nordstrom (1991).

${ }^{3}$ Langmuir et al. (2006). ${ }^{4}$ Zhu et al. (2005) . 
Table 3. Standard state properties of the aqueous species involved in Eq. (11) in SUPCRTBL

database and the thermodynamic properties for dawsonite

\begin{tabular}{|c|c|c|c|c|c|c|}
\hline & $\mathrm{Na}^{+}$ & $\mathrm{Al}(\mathrm{OH})_{4}^{-}$ & $\mathrm{HCO}_{3}^{-}$ & $\mathrm{H}_{2} \mathrm{O}$ & $\begin{array}{l}{ }^{\text {a } D a w s o n i t e ~ i n ~} \\
\text { this study }\end{array}$ & $\begin{array}{c}\text { Dawsonite in } \\
\text { Benezeth et al. (2007) }\end{array}$ \\
\hline${ }^{\mathrm{b}} \Delta_{f} G^{\mathrm{o}}{ }_{T r, P r}$ & -261.881 & -1305.772 & -586.94 & -237.183 & -1782.3 & $-1782 \pm 2$ \\
\hline${ }^{\mathrm{b}} \Delta_{f} H^{\mathrm{o}}{ }_{T r, P r}$ & -240.3 & -1483.575 & -689.933 & -285.838 & -1939.1 & $-1964 \pm 7$ \\
\hline${ }^{\mathrm{c}} S^{\mathrm{o}}{ }_{T r, P r}$ & 58.409 & 103.5456 & 98.449 & 69.923 & 137.7 & $132 \pm 2$ \\
\hline
\end{tabular}


Table 4. Comparison of updates of thermodynamic properties of aqueous and mineral species from SUPCRT92.dat database

\begin{tabular}{l}
\hline \multicolumn{1}{c}{ SUPCRT96.dat } \\
\hline $\begin{array}{l}\text { Al-bearing species and } \\
\text { NaOH }{ }^{\circ} \text { from Pokrovsk } \\
\text { and Helgeson (1995). }\end{array}$ \\
\\
Metal-organic \\
complexes and other \\
organic compounds \\
from Shock (1992); \\
Shock (1993); Shock \\
and Koretsky (1993); \\
Shock and Koretsky \\
(1995); Shock and \\
McKinnon (1993); \\
Schulte and Shock \\
(1993); Haas et al. \\
(1995); and references \\
therein.
\end{tabular}

Aqueous

Species

\begin{abstract}
Metal-organic complexes and other organic compounds from Shock (1992); Shock (1993); Shock and Koretsky (1993); Shock and Koretsky (1995); Shock and McKinnon (1993); Schulte and Shock (1993); Haas et al. (1995); and references therein.
\end{abstract}

Uranium from Shock et Palladium from Sassani al. (1997a); Platinumand Shock (1998).
Group from Sassani and Shock (1998).
Uranium from Shock et al. (1997a); Platinum-Group from Sassani and Shock (1998); Actinides from Murphy and Shock (1999).
Metal-organic complexes and other organic compounds from Shock (1992); Shock (1993); Shock and Koretsky (1993); Shock and Koretsky (1995); Shock and McKinnon (1993); Schulte and Shock (1993); Haas et al. (1995); Shock (1995); Dale et al. (1997); Haas and Shock (1999); Prapaipong et al. (1999); Amend and Shock (2001); Amend and Plyasunov (2001); Plyasunov and Shock (2001); Schulte and Rogers (2004); Dick et al. (2006); LaRowe and Helgeson (2006a, 2006b); Shock (2009); and references therein.

Uranium from Shock et al. (1997a); Platinum-Group from Sassani and Shock (1998).. $\mathrm{SiO}_{2}{ }^{\circ}$ and $\mathrm{HSiO}_{3}{ }^{-}$from Apps and Spycher (2004), (Rimstidt (1997) and Stefansson (2001) As-bearing species from Nordstrom and Archer (2002). Metal-arsenate and metalarsenite aqueous complexes from Marini and Accornero (2010).

\section{All other species from All other species from} Sverjensky et al. (1997) Sverjensky et al. (1997) All other species from Sverjensky and those internally and those internally consistent to Sverjensky et al. (1997)in earlier Helgeson and coworkers' publications consistent to Sverjensky et al. (1997)in earlier Helgeson and coworkers' publications et al. (1997) and those internally consistent to Sverjensky et al.

(1997)in earlier Helgeson and coworkers' publications
All other species from Sverjensky et al. (1997) and those internally consistent to Sverjensky et al. (1997)in earlier Helgeson and coworkers' publications

Holland and Powell (2011); Boehmite from Hemingway et al. (1991); Gibbsite from Robie et al. (1978); Dawsonite from this study; Arsenopyrite from Ball and Nordstrom (1991); Scorodite and Ferric-As,am from Langmuir et al. (2006); Barium-As and Barium-H-As from Zhu et al. (2005); all other As-bearing solids from Nordstrom and Archer (2002). 

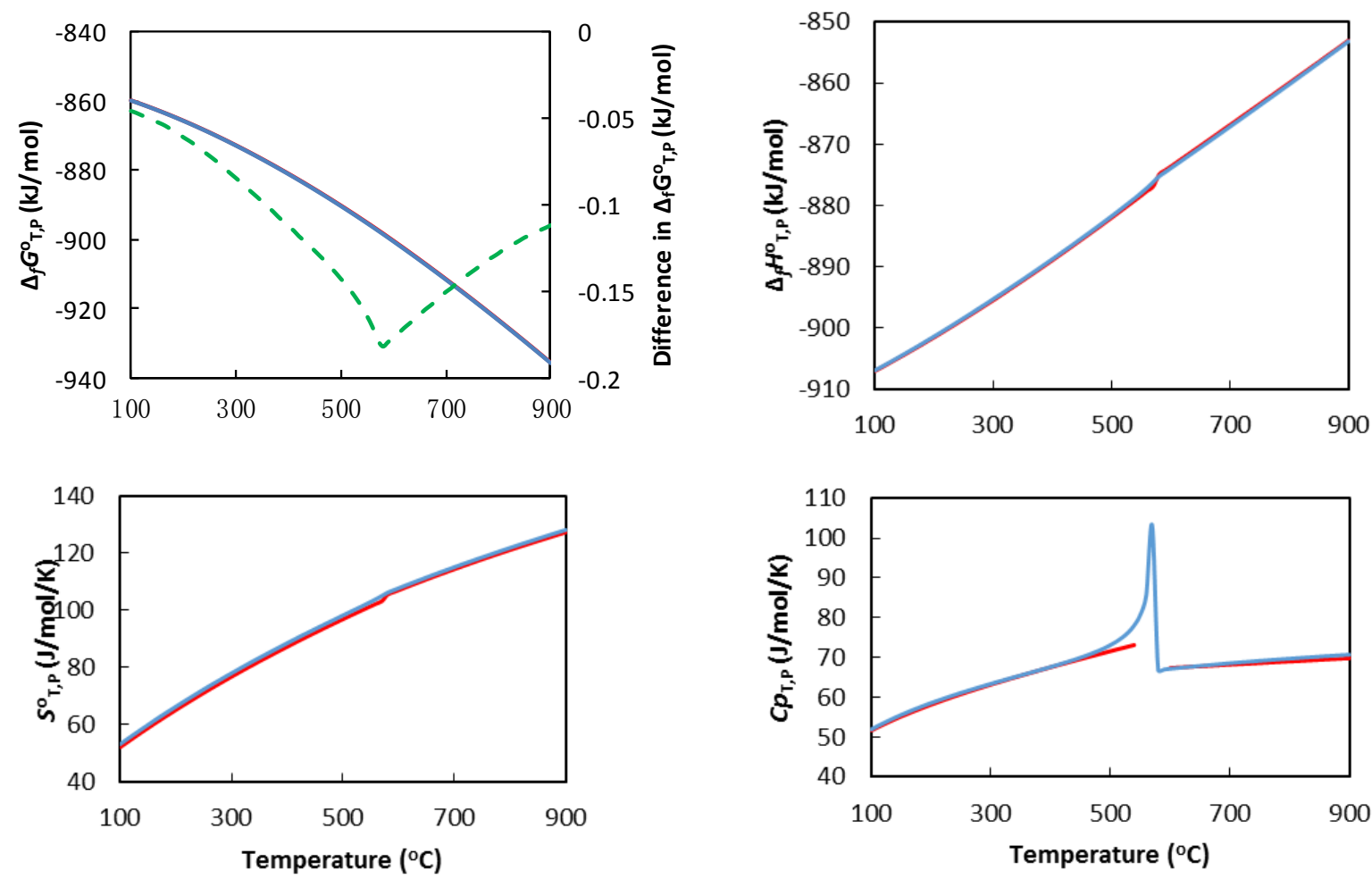

Figure 1. Comparison of thermodynamic properties of quartz as a function of temperature at 1 bar between SUPCRTBL and SUPCRT92. SUPCRTBL (Blue lines) has better prediction of heat capacity lambda anomaly of quartz near its phase transition temperature than SUPCRT92 (Red lines). For $\Delta_{f} G_{T, P}^{0}$, the red and blue line overlap with each other (The difference is shown with green dashed line). The largest difference on $\Delta_{f} G_{T, P}^{0}$ occurs near the phase transition temperature, but all differences are small. 


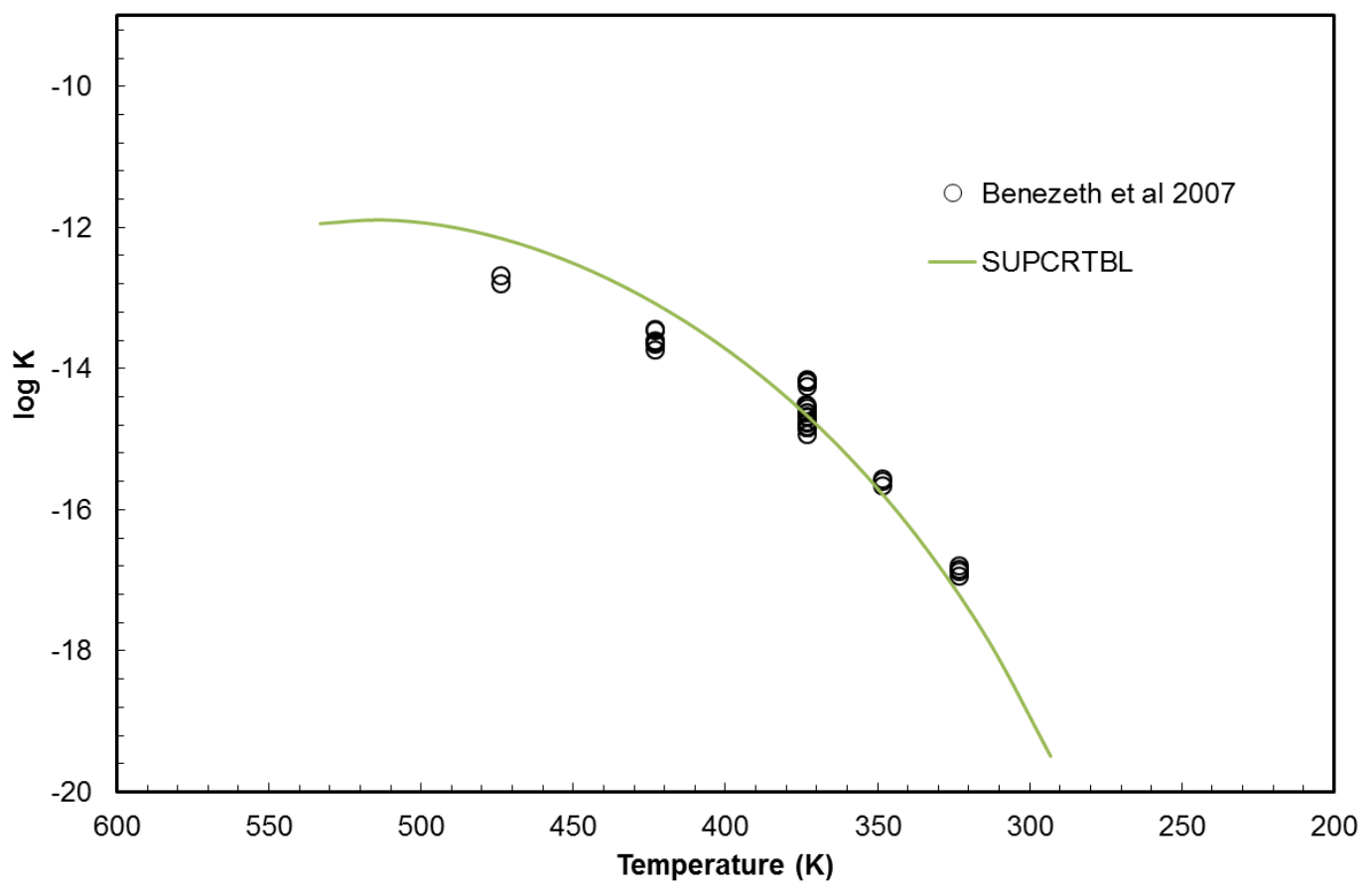

Figure 2. Log K's of dawsonite reaction (Eq. 10) as a function of temperature. Symbols stand for the solubility data in Benezeth et al. (2007). The line denotes calculation result of SUPCRTBL with derived $\Delta_{f} G^{\mathrm{o}} T r, \operatorname{Pr}$ value. 
(a)

\section{FORSTERI TE}

fo

HP11
Mg2Si 104

$\mathrm{Mg}$ ( 2) Si ( 1) O 4)

30. MAY. 14

- 2172. 57

95. 10

4. 366

- 2053. 50

0. 1494

603. 80

- 1. 8697

1285. 0

- 0.0030

3. 84

7. 000

\begin{tabular}{|l|l|l|l|l|}
\hline Mineral name & Chemical formula & & & \\
\hline Mineral abbreviation & Chemical stoichiometry & & & \\
\hline Database & Date last modified & & & \\
\hline$\Delta_{f} G_{T r, P r}^{\circ}(\mathrm{kJ} / \mathrm{mol})$ & $\Delta_{f} H^{0} T_{r}, P_{r}(\mathrm{~kJ} / \mathrm{mol})$ & $S^{0} T_{r, P r}(\mathrm{~J} / \mathrm{mol} / \mathrm{K})$ & $V_{T r, P r}^{0}(\mathrm{~J} / \mathrm{bar})$ & \\
\hline$a(\mathrm{~kJ} / \mathrm{mol} / \mathrm{K})$ & $b\left(10^{2} \mathrm{~kJ} / \mathrm{mol} / \mathrm{K}^{2}\right)$ & $c(\mathrm{JJ} \cdot \mathrm{K} / \mathrm{mol})$ & $d\left(\mathrm{~kJ} / \mathrm{mol} / \mathrm{K}^{-0.5}\right)$ & \\
\hline$\alpha_{0}\left(10^{5} \mathrm{~K}^{-1}\right)$ & $\kappa_{0}\left(\mathrm{kbar}^{-1}\right)$ & $\kappa_{0}^{\prime}(1)$ & $\kappa^{\prime \prime}{ }_{0}(\mathrm{kbar})$ & $\begin{array}{l}\text { Number of atoms in } \\
\text { chemical formula }\end{array}$ \\
\hline$T_{\max }$ & & & & \\
\hline
\end{tabular}

(b)

\section{QUARTZ}

q

HP11
Si 102

Si ( 1) O 2)

30. MAY. 14

- 856. 28

- 910.70

41. 43

2. 269

0. 0929

- 0.0642

- 714. 90

- 0.7161

0. 00

730. 0

6. 00

$-0.0082$

3. 000

847. 00

4. 95

0. 1188

9999. 0

\begin{tabular}{|l|l|l|l|l|}
\hline Mineral name & Chemical formula & & & \\
\hline Mineral abbreviation & Chemical stoichiometry & & & \\
\hline Database & Date last modified & & & \\
\hline$\Delta_{f} G^{0}{ }_{T r}, P_{r}(\mathrm{~kJ} / \mathrm{mol})$ & $\Delta_{f} H^{0}{ }_{T, P r}(\mathrm{~kJ} / \mathrm{mol})$ & $S^{0}{ }_{T, P r}(\mathrm{~J} / \mathrm{mol} / \mathrm{K})$ & $V^{0}{ }_{T, P r}(\mathrm{~J} / \mathrm{bar})$ & \\
\hline$a(\mathrm{~kJ} / \mathrm{mol} / \mathrm{K})$ & $b\left(10^{5} \mathrm{~kJ} / \mathrm{mol} / \mathrm{K}^{2}\right)$ & $c(\mathrm{~kJ} \cdot \mathrm{K} / \mathrm{mol})$ & $d\left(\mathrm{~kJ} / \mathrm{mol} / \mathrm{K}^{-0.5}\right)$ & \\
\hline$\alpha_{0}\left(10^{5} \mathrm{~K}^{-1}\right)$ & $\kappa_{0}\left(\mathrm{kbar}{ }^{-1}\right)$ & $\kappa_{0}^{\prime}(1)$ & $\kappa^{\prime \prime}{ }_{0}(\mathrm{kbar})$ & $\begin{array}{l}\text { Number of atoms in } \\
\text { chemical formula }\end{array}$ \\
\hline$T_{\mathrm{C}}{ }^{0}(\mathrm{~K})$ & $S_{\max }(\mathrm{J} / \mathrm{mol} / \mathrm{K})$ & $V_{\max }(\mathrm{J} / \mathrm{bar})$ & & \\
\hline$T_{\max }$ & & & & \\
\hline
\end{tabular}

Figure 3. The generic species block for minerals in spronsbl.dat. (a) Minerals that do not undergo phase transitions. Data for forsterite are used here as an example. (b) Minerals that undergo phase transitions. Landau model parameters from HP11 and HP98 are added for calculating phase transitions. $T_{\max }$ is the upper limit of the heat capacity parameters left over from SUPCRT92. Because HP11 does not give the upper limit for individual minerals, we set 
a default value of 9999K. Users are responsible for minding the upper limits by themselves. $T \mathrm{c}^{\circ}$, Smax, and $V \max$ denote critical temperature at 1 bar, entropy and volume of disordering at $T \mathrm{c}^{\circ}$, respectively. All other symbols in the figure are defined in preceding text. 


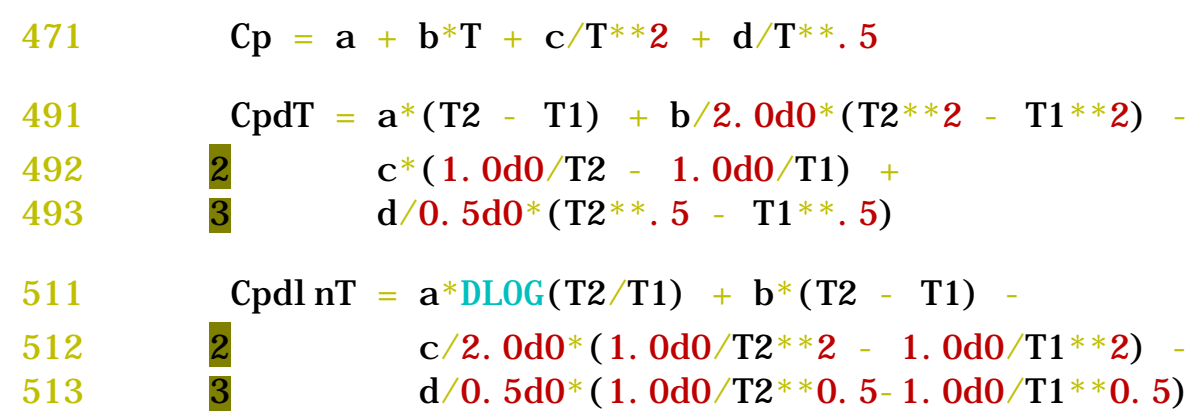

Figure 4: Updated piece of code for the heat capacity in Cp, CpdT, CpdlnT, respectively. 


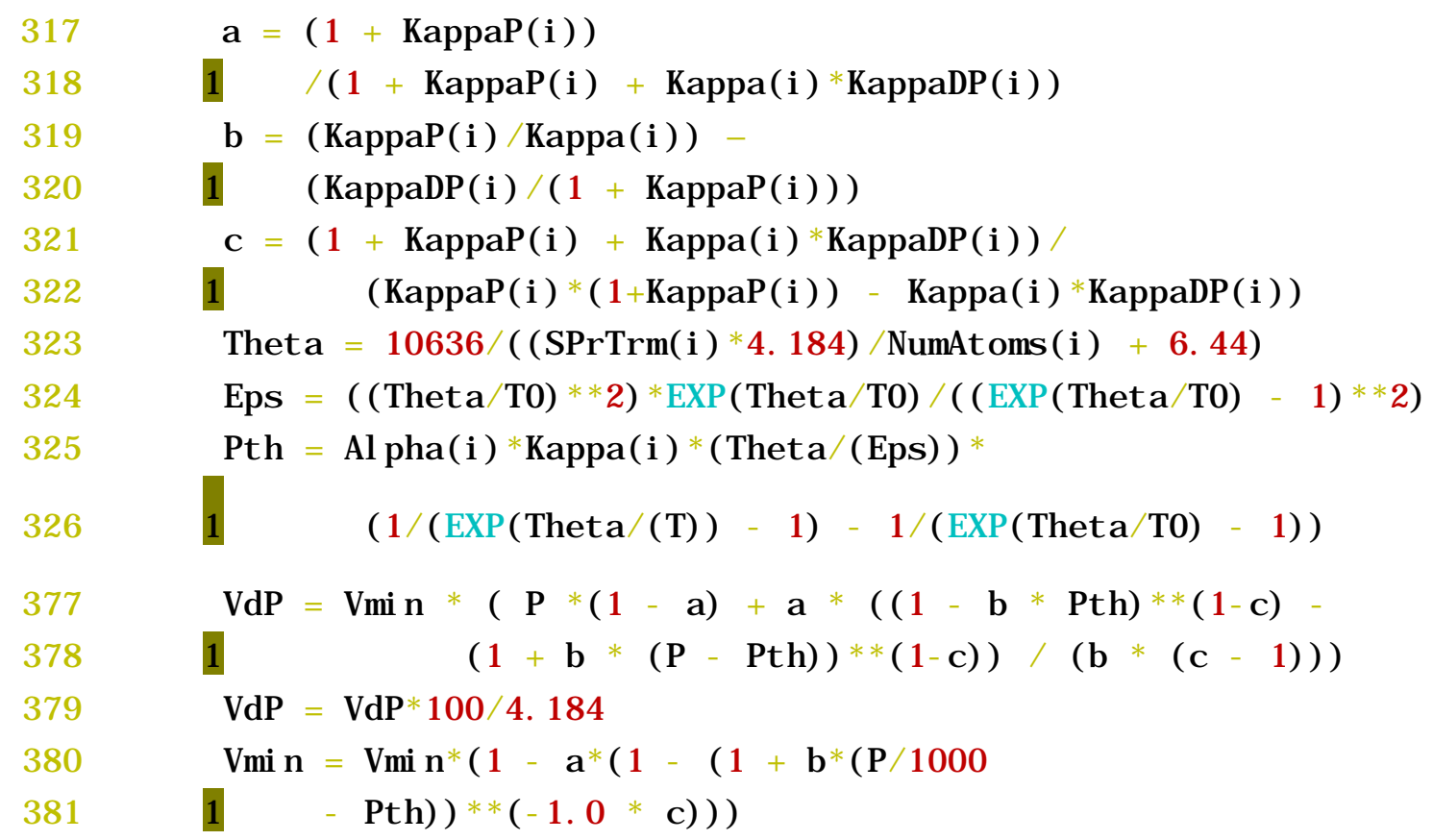

Figure 5: Updated piece of code for the new volume contribution 
(a)

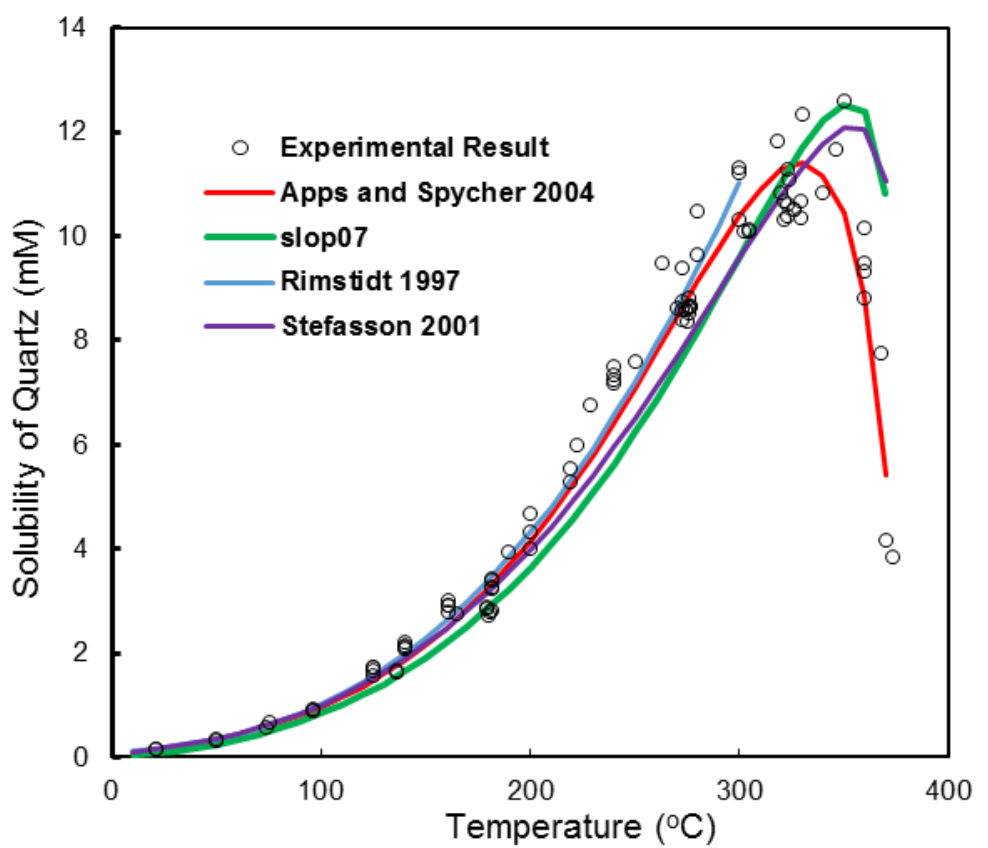

(b)

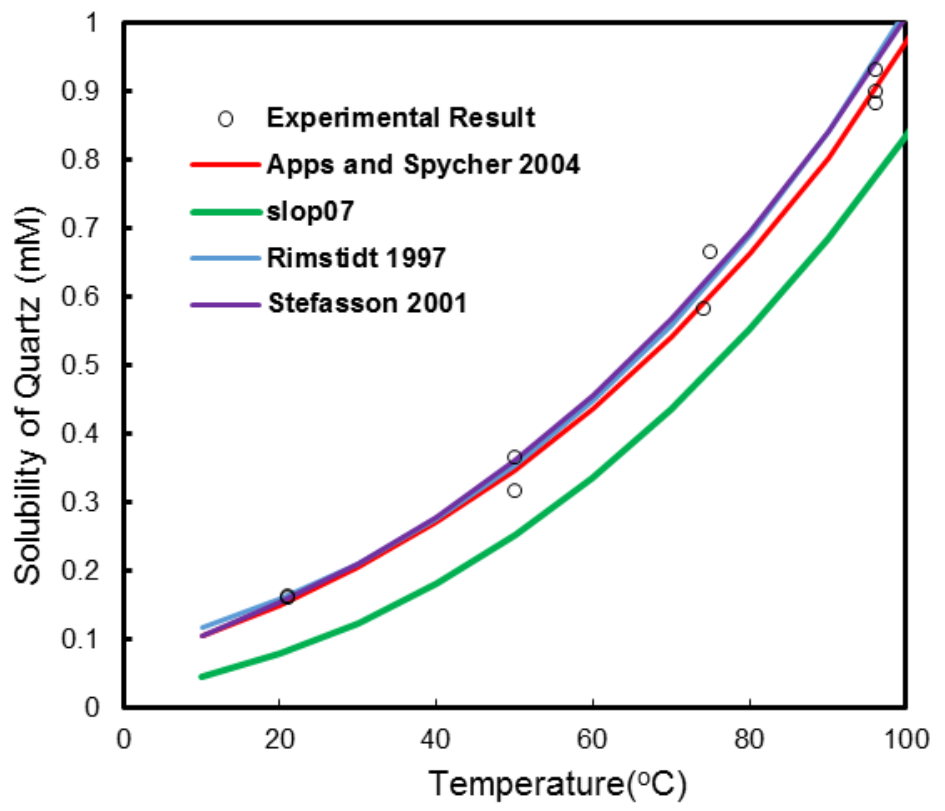

Figure 6. Comparison between quartz solubility experimetal data measured and compiled by

Rimstidt (1997) (Black circles) and calculated results using SUPCRTBL and SUPCRT92. 
Rimstidt (1997) (Blue line): empirical Van’t Hoff equation; slop07 (Green line): quartz from HDNB and $\mathrm{SiO}_{2}$ (aq) from Shock et al. (1997b); Stefasson 2001 (Purple line): quartz from $\mathrm{HP} 11, \mathrm{H}_{4} \mathrm{SiO}_{4}{ }^{\circ}$ (aq) from Stefansson (2001); Apps and Spycher 2004 (Red line): quartz from HP11 and $\mathrm{SiO}_{2}(\mathrm{aq})$ from Xu et al. (2004). (b) is an enlargement of (a) at low temperature. Fig 6 (b) includes experimental data from Rimstidt (1997) only. 


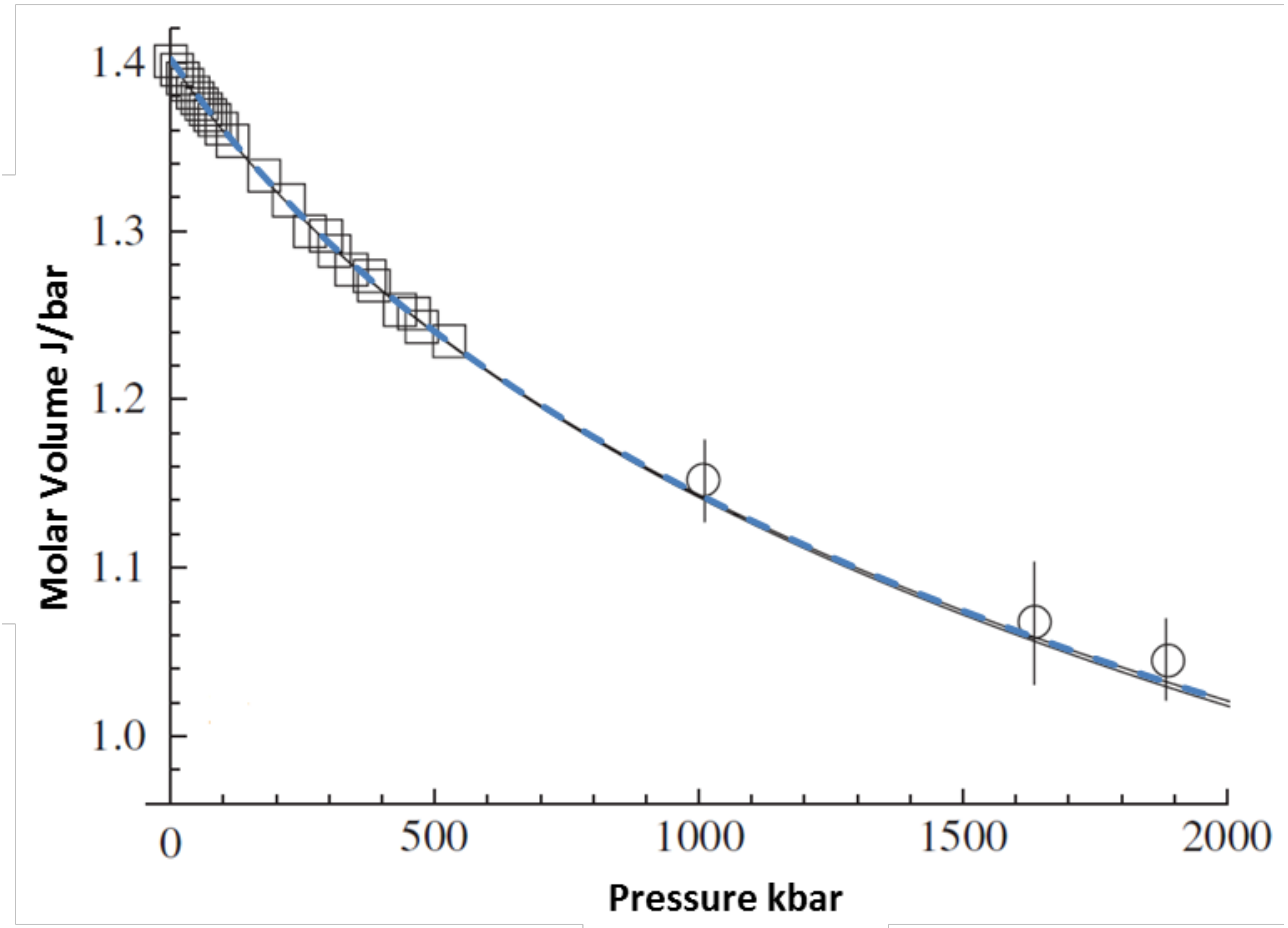

Figure 7. SUPCRTBL calculated molar volume of stishovite at $298.15 \mathrm{~K}$ as a fucntion of pressure (blue dashed line), which was overlain onto HP11 Fig 4 (black solid line). Squares and circles are experimental data reported by HP11. 


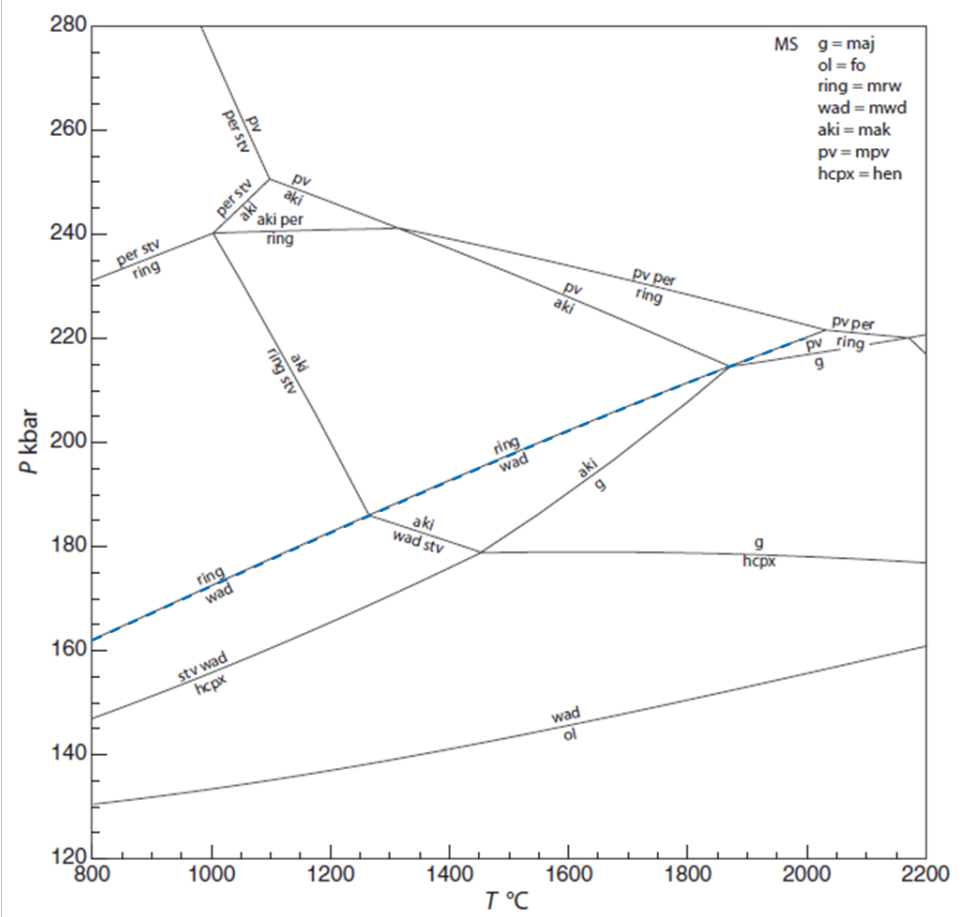

Figure 8. SUPCRTBL calculated phase boundary between Mg-ringwoodite and Mgwadsleyite as a function of temeprature and pressure (blue dashed line), which is overlain onto HP11 Fig 9 (black lines). 


\section{References:}

Amend, J.P. and Plyasunov, A.V. (2001) Carbohydrates in thermophile metabolism: calculation of the standard molal thermodynamic properties of aqueous pentoses and hexoses at elevated temperatures and pressures. Geochimica et Cosmochimica Acta 65, 3901-3917. Amend, J.P. and Shock, E.L. (2001) Energetics of overall metabolic reactions of thermophilic and hyperthermophilic Archaea and Bacteria. FEMS microbiology reviews 25, 175-243.

Anderson, G.M. (2008) Thermodynamics of natural systems. Cambridge University Press. Andre, L., Audigane, P., Azaroual, M. and Menjoz, A. (2007) Numerical modeling of fluid-rock chemical interactions at the supercritical $\mathrm{CO} 2$-liquid interface during $\mathrm{CO} 2$ injection into a carbonate reservoir, the Dogger aquifer (Paris Basin, France). Energy Conversion and Management 48, 17821797.

Bachu, S. (2008) CO2 storage in geological media: Role, means, status and barriers to deployment. Progress in Energy and Combustion Science 34, 254-273.

Ball, J.W. and Nordstrom, D.K. (1991) User's manual for WATEQ4F, with revised thermodynamic data base and test cases for calculating speciation of major, trace, and redox elements in natural waters. U.S.Geological Survey Open File Report 91-183.

Benezeth, P., Palmer, D.A., Anovitz, L.M. and Horita, J. (2007) Dawsonite synthesis and reevaluation of its thermodynamic properties from solubility measurements: Implications for mineral trapping of CO2. Geochimica Et Cosmochimica Acta 71, 4438-4455.

Berman, R.G. (1988) Internally-consistent thermodynamic data for minerals in the system $\mathrm{Na}_{2} \mathrm{O}-\mathrm{K}_{2} \mathrm{O}-$ CaO-MgO-FeO- $\mathrm{Fe}_{2} \mathrm{O}_{3}-\mathrm{Al}_{2} \mathrm{O}_{3}-\mathrm{SiO}_{2}-\mathrm{TiO}_{2}-\mathrm{H}_{2} \mathrm{O}-\mathrm{CO}_{2}$. Journal of Petrology 29, 445-522.

Cox, J., Wagman, D.D. and Medvedev, V.A. (1989) CODATA key values for thermodynamics. Hemisphere Publishing Corp., New York.

Dale, J.D., Shock, E.L., Macleod, G., Aplin, A.C. and Larter, S.R. (1997) Standard partial molal properties of aqueous alkylphenols at high pressures and temperatures. Geochimica et Cosmochimica Acta 61, 4017-4024.

Dick, J., LaRowe, D. and Helgeson, H. (2006) Temperature, pressure, and electrochemical constraints on protein speciation: Group additivity calculation of the standard molal thermodynamic properties of ionized unfolded proteins. Biogeosciences 3, 311-336.

Ferrante, M.J., Stuve, J.M. and Richardson, D.W. (1976) Thermodynamic data for synthetic dawsonite. U.S. Bureau of Mines Report Investigation, 8129, Washington, D.C., 13p.

Freund, J. and Ingalls, R. (1989) Inverted isothermal equations of state and determination of $B<s u b>$ $0</$ sub $>, B^{\prime}<$ sub $>0</$ sub $>$ and $B<$ sub $>0</$ sub $>$. Journal of Physics and Chemistry of Solids 50, 263268.

Fukushi, K. and Sverjensky, D.A. (2007) A predictive model (ETLM) for arsenate adsorption and surface speciation on oxides consistent with spectroscopic and theoretical molecular evidence. Geochimica et Cosmochimica Acta 71, 3717-3745.

Gunnarsson, I. and Arnórsson, S. (2000) Amorphous silica solubility and the thermodynamic properties of $\mathrm{H}_{4 \mathrm{SiO}^{\circ} 4} 4$ in the range of $0^{\circ}$ to $350^{\circ} \mathrm{C}$ at Psat. Geochimica et Cosmochimica Acta 64, 2295-2307. 
Haas, J.R. and Shock, E.L. (1999) Halocarbons in the environment: estimates of thermodynamic properties for aqueous chloroethylene species and their stabilities in natural settings. Geochimica et Cosmochimica Acta 63, 3429-3441.

Haas, J.R., Shock, E.L. and Sassani, D.C. (1995) Rare earth elements in hydrothermal systems: estimates of standard partial molal thermodynamic properties of aqueous complexes of the rare earth elements at high pressures and temperatures. Geochimica et Cosmochimica Acta 59, 43294350.

Helgeson, H.C., Delany, J.M., Nesbitt, H.W. and Bird, D.K. (1978) Summary and critique of the thermodynamic properties of rock forming minerals. American Journal of Science 278A, 569-592. Hemingway, B., Robie, R., Fisher, J. and Wilson, W. (1977) Heat capacities of gibbsite, Al(OH)3, between 13 and $480 \mathrm{~K}$ and magnesite, MgCO3, between 13 and $380 \mathrm{~K}$ and their standard entropies at $289.15 \mathrm{~K}$, and the heat capacities of calorimetry conference benzoic acid between 12 and $316 \mathrm{~K}$. J. Res. US Geol. Surv. 5.

Hemingway, B.S., Robie, R.A. and Apps, J.A. (1991) Revised values for the thermodynamic properties of boehmite, $\mathrm{AlO}(\mathrm{OH})$, and related species and phases in the system Al-H-O. American Mineralogist, 445-457.

Hemingway, B.S., Robie, R.A. and Kittrick, J.A. (1978) Revised values for the Gibbs free energy of formation of $\mathrm{Al}(\mathrm{OH}) 4 \mathrm{aq}^{-}$, diaspore, boehmite and bayerite at $298.15 \mathrm{~K}$ and $1 \mathrm{bar}$, the thermodynamic properties of kaolinite to $800 \mathrm{~K}$ and $1 \mathrm{bar}$, and the heats of solution of several gibbsite samples. Geochimica et Cosmochimica Acta 42, 1533-1543.

Holland, T. and Carpenter, M. (1986) Aluminium/silicon disordering and melting in sillimanite at high pressures. Nature 320, 151-153.

Holland, T. and Powell, R. (2011) An improved and extended internally consistent thermodynamic dataset for phases of petrological interest, involving a new equation of state for solids. Journal of Metamorphic Geology 29, 333-383.

Holland, T., Redfern, S.A. and Pawley, A. (1996) Volume behavior of hydrous minerals at high pressure and temperature: II. Compressibilities of lawsonite, zoisite, clinozoisite, and epidote. American Mineralogist 81, 341-348.

IPCC (2005) Special Report on carbon Dioxide Capture and Storage.

http://www.unep.ch/ipcc/activity/srccs/.

Johnson, J.W., Morris, J. and Nitao, J. (2004a) Modeling the long-term isolation performance of natural and engineered geologic $\mathrm{CO} 2$ storage sites. United States. Department of Energy.

Johnson, J.W., Nitao, J.J. and Knauss, K.G. (2004b) Reactive transport modeling of CO2 storage in saline aquifers to elucidate fundamental processes, trapping mechanisms and sequestration partitioning. Geological storage of carbon dioxide 233, 107-128.

Johnson, J.W., Oelkers, E.H. and Helgeson, H.C. (1992) SUPCRT92 - A software package for calculating the standard molal thermodynamic properties of minerals, gases, aqueous species, and reactions from 1-bar to 5000 -bar and $0^{\circ} \mathrm{C}$ to $1000^{\circ} \mathrm{C}$. Computers \& Geosciences 18 , 899-947.

Langmuir, D., Mahoney, J. and Rowson, J. (2006) Solubility products of amorphous ferric arsenate and crystalline scorodite ( $\mathrm{FeAsO} \cdot 2 \mathrm{H} 2 \mathrm{O}$ ) and their application to arsenic behavior in buried mine tailings Geochim. Cosmochim. Acta 70, 2942-2956.

LaRowe, D.E. and Helgeson, H.C. (2006a) Biomolecules in hydrothermal systems: calculation of the standard molal thermodynamic properties of nucleic-acid bases, nucleosides, and nucleotides at elevated temperatures and pressures. Geochimica et Cosmochimica Acta 70, 4680-4724. 
LaRowe, D.E. and Helgeson, H.C. (2006b) The energetics of metabolism in hydrothermal systems: calculation of the standard molal thermodynamic properties of magnesium-complexed adenosine nucleotides and NAD and NADP at elevated temperatures and pressures. Thermochimica acta 448, 82-106.

Liu, F.Y., P. Lu, C. Zhu and Y. Xiao (2011) Coupled reactive transport modeling of CO2 Sequestration in the Mt. Simon Sandstone Formation, Midwest U.S.A. The International Journal of Greenhouse Gas Control 52, 297-307.

Lu, P. and Zhu, C. (2011) Arsenic Eh-pH diagrams at 25 degrees C and 1 bar. Environmental Earth Sciences 62, 1673-1683.

Maier, C.G. and Kelley, K. (1932) An equation for the representation of high-temperature heat content data1. Journal of the American chemical society 54, 3243-3246.

Marini, L. and Accornero, M. (2007) Prediction of the thermodynamic properties of metal-arsenate and metal-arsenite aqueous complexes to high temperatures and pressures and some geological consequences. Environmental geology 52, 1343-1363.

Marini, L. and Accornero, M. (2010) Erratum to: Prediction of the thermodynamic properties of metal-arsenate and metal-arsenite aqueous complexes to high temperatures and pressures and some geological consequences. Environmental Earth Sciences 59, 1601-1606.

McKnight-Whitford, A., Chen, B.W., Naranmandura, H., Zhu, C. and Le, X.C. (2010) New Method and Detection of High Concentrations of Monomethylarsonous Acid Detected in Contaminated Groundwater. Environmental Science \& Technology 44, 5875-5880.

Nordstrom, D.K. and Archer, D.G. (2002) Arsenic thermodynamic data and environmental geochemistry, in: Welch, A.H., Stollenwerk, K.G. (Eds.), Arsenic in ground water. Springer. Oelkers, E.H., Bénézeth, P. and Pokrovski, G.S. (2009) Thermodynamic databases for water-rock interaction. Reviews in Mineralogy and Geochemistry 70, 1-46.

Oremland, R.S. and Stolz, J.F. (2003) The Ecology of Arsenic. Science 300, 939-944.

Pawley, A., Redfern, S.A. and Holland, T. (1996) Volume behavior of hydrous minerals at high pressure and temperature: I. Thermal expansion of lawsonite, zoisite, clinozoisite, and diaspore. American Mineralogist 81, 335-340.

Plyasunov, A.V. and Shock, E.L. (2001) Correlation strategy for determining the parameters of the revised Helgeson-Kirkham-Flowers model for aqueous nonelectrolytes. Geochimica et Cosmochimica Acta 65, 3879-3900.

Pokrovski, G.S., Kara, S. and Roux, J. (2002) Stability and solubility of arsenopyrite, FeAsS, in crustal fluids. Geochim. Cosmochim. Acta 66, 2361-2378.

Pokrovskii, V.A. and Helgeson, H.C. (1995) Thermodynamic properties of aqueous species and the solubilities of minerals at high pressures and temperatures: The system $\mathrm{Al}_{2} \mathrm{O}_{3}-\mathrm{H}_{2} \mathrm{O}-\mathrm{NaCl}$. American Journal of Science 295, 1255-1342.

Prapaipong, P., Shock, E.L. and Koretsky, C.M. (1999) Metal-organic complexes in geochemical processes: temperature dependence of the standard thermodynamic properties of aqueous complexes between metal cations and dicarboxylate ligands. Geochimica et Cosmochimica Acta 63, 2547-2577.

Rimstidt, J.D. (1997) Quartz solubility at low temperatures. Geochimica et Cosmochimica Acta 61, 2553-2558. 
Robie, R.A. and Hemingway, B.S. (1995) Thermodynamic properties of minerals and related substances at $298.15 \mathrm{~K}$ and 1 bar ( $10^{5}$ pascals) pressure and at higher temperatures. U.S. Geological Survey Bulletin 2131, 456p.

Robie, R.A., Hemingway, B.S. and Fisher, J.R. (1978) Thermodynamic properties of minerals and related substances at $298.15 \mathrm{~K}$ and 1 bar (105 pascals) pressure and at higher temperatures. U.S. Geological Survey Bulletin 1452, 456p.

Sassani, D.C. and Shock, E.L. (1998) Solubility and transport of platinum-group elements in supercritical fluids: summary and estimates of thermodynamic properties for ruthenium, rhodium, palladium, and platinum solids, aqueous ions, and complexes to $1000^{\circ} \mathrm{C}$ and $5 \mathrm{kbar}$. Geochimica et Cosmochimica Acta 62, 2643-2671.

Schulte, M.D. and Rogers, K.L. (2004) Thiols in hydrothermal solution: standard partial molal properties and their role in the organic geochemistry of hydrothermal environments. Geochimica et Cosmochimica Acta 68, 1087-1097.

Schulte, M.D. and Shock, E.L. (1993) Aldehydes in hydrothermal solution: Standard partial molal thermodynamic properties and relative stabilities at high temperatures and pressures. Geochimica et cosmochimica acta 57, 3835-3846.

Shock, E.L. (1992) Stability of peptides in high-temperature aqueous solutions. Geochimica et cosmochimica acta 56, 3481-3491.

Shock, E.L. (1993) Hydrothermal dehydration of aqueous organic compounds. Geochimica et cosmochimica acta 57, 3341-3349.

Shock, E.L. (1995) Organic acids in hydrothermal solutions: Standard molal thermodynamic properties of carboxylic acids and estimates of dissociation constants at high temperatures and pressures. Amer. Jour. Science 295, 496-580.

Shock, E.L. (2009) Minerals as energy sources for microorganisms. Economic Geology 104, 12351248.

Shock, E.L. and Koretsky, C.M. (1993) Metal-organic complexes in geochemical processes:

Calculation of standard partial molal thermodynamic properties of aqueous acetate complexes at high pressures and temperatures. Geochimica et Cosmochimica Acta 57, 4899-4922.

Shock, E.L. and Koretsky, C.M. (1995) Metal-Organic Complexes in Geochemical Processes -

Estimation of Standard Partial Molal Thermodynamic Properties of Aqueous Complexes between Metal-Cations and Monovalent Organic-Acid Ligands at High-Pressures and Temperatures.

Geochimica Et Cosmochimica Acta 59, 1497-1532.

Shock, E.L. and McKinnon, W.B. (1993) Hydrothermal processing of cometary volatiles-Applications to Triton. Icarus 106, 464-477.

Shock, E.L., Sassani, D.C. and Betz, H. (1997a) Uranium in geologic fluids: Estimates of standard partial molal properties, oxidation potentials, and hydrolysis constants at high temperatures and pressures. Geochimica et Cosmochimica Acta 61, 4245-4266.

Shock, E.L., Sassani, D.C., Willis, M. and Sverjensky, D.A. (1997b) Inorganic species in geologic fluids: Correlations among standard molal thermodynamic properties of aqueous ions and hydroxide complexes. Geochimica et Cosmochimica Acta 61, 907-950.

Smedley, P.L. and Kinniburgh, D.G. (2002) A review of the source, behaviour and distrbution of arsenic in natural waters. Applied Geochemistry 17, 517-568.

Stefansson, A. (2001) Dissolution of primary minerals of basalt in natural waters: I. Calculation of mineral solubilities from $0 \mathrm{C}$ to $350 \mathrm{C}$. Chemical Geology 172, 225-250. 
Strazisar, B.R., Zhu, C. and Hedges, S.W. (2006) Preliminary modeling of the long-term fate of $\mathrm{CO}_{2}$ following injection into deep geological formations. Environmental Geosciences 13, 1-15.

Sverjensky, D.A. and Fukushi, K. (2006) A predictive model (ETLM) for As(III) adsorption and surface speciation on oxides consistent with spectroscopic data. Geochimica et Cosmochimica Acta 70, 3778-3802.

Sverjensky, D.A., Shock, E.L. and Helgeson, H.C. (1997) Prediction of the thermodynamic properties of aqueous metal complexes to $5 \mathrm{~Kb}$ and $1000{ }^{\circ} \mathrm{C}$. Geochimica et Cosmochimica Acta 61, 1359-1412. Swartz, C.H., Blute, N.K., Badruzzman, B., Ali, A., Brabander, D., Jay, J., Besancon, J., Islam, S., Hemond, H.F. and Harvey, C.F. (2004) Mobility of arsenic in a Bangladesh aquifer: Inferences from geochemical profiles, leaching data, and mineralogical characterization. Geochim. Cosmochim. Acta 68, 4539-4557

Tagirov, B. and Schott, J. (2001) Aluminum speciation in crustal fluids revisited. Geochimica et Cosmochimica Acta 65, 3965-3992.

Tutolo, B.M., Kong, X.-Z., Seyfried Jr, W.E. and Saar, M.O. (2014) Internal consistency in aqueous geochemical data revisited: Applications to the aluminum system. Geochimica et Cosmochimica Acta 133, 216-234.

Wagman, D.D., Evans, W.H., Parker, V.B., Schumm, R.H., Halow, I., Bailey, S.M., Churney, K.L. and Nuttall, R.L. (1982) The NBS tables of chemical thermodynamic properties - selected values for inorganic and C-1 and C-2 organic-substances in SI units. Journal of Physical and Chemical Reference Data 11 supplement 2, 392p.

Welch, A.H., Westjohn, D.B., Helsel, D.R. and Wanty, R.B. (2000) Arsenic in ground water of the United States: Occurence and geochemistry. Ground Water 38, 589-604.

Wesolowski, D.J. (1992) Aluminum Speciation and Equilibria in Aqueous-Solution .1. the Solubility of Gibbsite in the System Na-K-Cl-OH-Al(OH)$)_{4}$ from $0^{\circ}$ to $100^{\circ} \mathrm{C}$. Geochimica et Cosmochimica Acta 56, 1065-1091.

$\mathrm{Xu}, \mathrm{T} .$, Apps, J.A. and Pruess, K. (2004) Numerical simulation of $\mathrm{CO}_{2}$ disposal by mineral trapping in deep aquifers. Applied Geochemistry 19, 917-936.

Zhang, G.R., Lu, P., Zhang, Y.L., Wei, X.M. and Zhu, C. (2015) Effects of rate law formulation on predicting $\mathrm{CO} 2$ sequestration in sandstone formations. International Journal of Energy Research 39, 1890-1908.

Zhu, C. and Lu, P. (2009) Alkali feldspar dissolution and secondary mineral precipitation in batch systems: 3. Saturation states of product minerals and reaction paths. Geochimica et Cosmochimica Acta 73, 3171-3200.

Zhu, C., Zhang, G., Lu, P., Meng, L. and Ji, X. (in press) Benchmark modeling of the Sleipner CO2 plume: Calibration to seismic data for the uppermost layer and model sensitivity analysis. International Journal of Greenhouse Gas Control.

Zhu, Y., Zhang, X., Xie, Q., Chen, Y., Wang, D., Liang, Y. and Lu, J. (2005) Solubility and stability of barium arsenate and barium hydrogen arsenate at 25 C. Journal of Hazardous Materials 120, 37-44. 